\title{
MMPs in learning and memory and neuropsychiatric disorders
}

\author{
Anna Beroun $^{1} \cdot$ Shiladitya Mitra ${ }^{1} \cdot$ Piotr Michaluk $^{1} \cdot$ Barbara Pijet $^{1} \cdot$ Marzena Stefaniuk $^{1} \cdot$ Leszek Kaczmarek $^{1}$
}

Received: 27 May 2019 / Revised: 27 May 2019 / Accepted: 29 May 2019 / Published online: 6 June 2019

(c) The Author(s) 2019

\begin{abstract}
Matrix metalloproteinases (MMPs) are a group of over twenty proteases, operating chiefly extracellularly to cleave components of the extracellular matrix, cell adhesion molecules as well as cytokines and growth factors. By virtue of their expression and activity patterns in animal models and clinical investigations, as well as functional studies with gene knockouts and enzyme inhibitors, MMPs have been demonstrated to play a paramount role in many physiological and pathological processes in the brain. In particular, they have been shown to influence learning and memory processes, as well as major neuropsychiatric disorders such as schizophrenia, various kinds of addiction, epilepsy, fragile X syndrome, and depression. A possible link connecting all those conditions is either physiological or aberrant synaptic plasticity where some MMPs, e.g., MMP-9, have been demonstrated to contribute to the structural and functional reorganization of excitatory synapses that are located on dendritic spines. Another common theme linking the aforementioned pathological conditions is neuroinflammation and MMPs have also been shown to be important mediators of immune responses.
\end{abstract}

Keywords Behavioral training $\cdot$ Schizophrenia $\cdot$ Autism $\cdot$ Epilepsy $\cdot$ Addiction

\begin{tabular}{|c|c|c|c|}
\hline \multicolumn{2}{|c|}{ Abbreviations } & \multirow{2}{*}{$\begin{array}{l}\text { FCD } \\
\text { FMRP }\end{array}$} & \multirow{2}{*}{$\begin{array}{l}\text { Focal cortical dysplasia } \\
\text { Fragile X mental retardation protein }\end{array}$} \\
\hline 3'UTR & 3' Untranslated region & & \\
\hline \multirow{2}{*}{ AMPA } & $\alpha$-Amino-3-hydroxy-5-methyl-4- & FPI & Fluid percussion injury \\
\hline & isoxazolepropionic acid & FXS & Fragile X syndrome \\
\hline \multirow[t]{2}{*}{ AMPAR } & $\alpha$-Amino-3-hydroxy-5-methyl-4- & GABA & $\gamma$-Aminobutyric acid \\
\hline & isoxazolepropionic acid receptor & ICAM-5 & Intercellular adhesion molecule-5 \\
\hline APP & $\beta$-Amyloid precursor protein & KA & Kainic acid \\
\hline ASD & Autism spectrum disorders & $\mathrm{KO}$ & Knockout \\
\hline $\mathrm{BD}$ & Bipolar disorder & LTD & Long-term depression \\
\hline BDNF & Brain derived neurotrophic factor & LTP & Long-term potentiation \\
\hline \multirow[t]{2}{*}{ CA1 } & Cornu Ammonis area 1 , subfield of & MD & Major depression \\
\hline & hippocampus & MMP & Matrix metalloproteinase \\
\hline \multirow[t]{2}{*}{ CA3 } & Cornu Ammonis area 3, subfield of & mRNA & Messenger ribonucleic acid \\
\hline & hippocampus & MT-MMP & Membrane-type MMP \\
\hline \multirow{2}{*}{$\begin{array}{l}\text { CAM } \\
\text { CCI }\end{array}$} & Cell adhesion molecule & NAc & Nucleus accumbens \\
\hline & Controlled cortical impact & NGF & Nerve growth factor \\
\hline $\mathrm{CPP}$ & Conditioned place preference & NMDA & $N$-methyl-D-aspartate \\
\hline ECM & Extracellular matrix & NMDAR & $N$-methyl-D-aspartate receptor \\
\hline $\mathrm{ECT}$ & Electro-convulsive therapy & PAR1 & Protease activated receptor 1 \\
\hline eIF4E & Eukaryotic initiation factor $4 \mathrm{E}$ & $\mathrm{PFC}$ & Prefrontal cortex \\
\hline \multirow[t]{2}{*}{ EPSP } & Excitatory postsynaptic potential & PNN & Perineuronal nets \\
\hline & & PTE & Post-traumatic epilepsy \\
\hline \multirow[t]{2}{*}{$\square$} & czmarek & PTZ & Pentylenetetrazole \\
\hline & ek@nencki.gov.pl & SAP-25 & Synaptosomal-associated protein of $25 \mathrm{kDa}$ \\
\hline \multirow[b]{2}{*}{ B } & & TBI & Traumatic brain iniury \\
\hline & TY, Nencki Institute, Pasteura 3, 02-093 Warsaw, & 1B1 & Iraumatic brain injury \\
\hline
\end{tabular}


TIMP Tissue inhibitor of metalloproteinases

TLE Temporal lobe epilepsy

tPA Tissue plasminogen activator

uPA Urokinase plasminogen activator

ZnT3 Zinc transporter 3

\section{Introduction to MMPs in the brain}

Extracellular matrix $(\mathrm{ECM})$ in the brain has emerged as an important reservoir of signaling molecules, which can influence synaptic plasticity, synaptogenesis, neurite outgrowth and other processes occurring in central nervous system. Many suggest now that "tetrapartite synapse" is a functional unit of the brain, where ECM plays equally important roles to pre-, post-synaptic terminals and glial cells' invaginations $[1,2]$. Matrix metalloproteinases (MMPs) are among the major modulators of ECM, providing precise proteolysis of its components, in addition to performing limited cleavage of cell adhesion molecules (CAMs), neurotrophins and cytokines [3, 4]. MMPs make up a family of over 20 proteins in humans and rodents (predominantly secreted, but six are membrane-bound), each encoded by a different gene. MMPs are a part of bigger, metzincin group of proteases, which all have $\mathrm{Zn}^{2+}$ and the conserved methionine residue in their active site $[3,5]$.

Based on their domain structure, MMPs are subdivided into eight groups, but all are composed of (starting from $\mathrm{N}$-terminus): a signal peptide, propeptide, catalytic domain and in most cases hinge region and hemopexin domain. The signal peptide is removed after the protein enters the endoplasmic reticulum. MMPs are expressed as inactive zymogens, where the propeptide has conserved cysteine residue binding $\mathrm{Zn}^{2+}$ in the active center of the enzyme. Activation occurs when the interaction between cysteine and $\mathrm{Zn}^{2+}$ is disrupted, which can be achieved by cleaving the propeptide off (by other proteases), as well as by other means, such as S-nitrosylation, detergents or sulphates [5, 6]. The catalytic domain of all MMPs has a highly conserved $\mathrm{Zn}^{2+}$ binding motif-HExGHxxGxxH (where $\mathrm{x}$ is any amino acid) and a distinct $\beta$-turn (usually ALMYP). That is why all MMPs have distinguishable, but often overlapping, substrate specificities. Moreover, the catalytic domain of MMPs requires binding of $\mathrm{Ca}^{2+}$ ions which are required for the stabilization of its active state [7]. Gelatinases (MMP-2 and -9) have additional fibronectin type II inserts, which are required for collagen and elastin binding and cleavage.

Most of MMPs (except of MMP-7, MMP-26 and MMP23 ) have hinge region and hemopexin domain, which is responsible for interaction with substrates, dimerization and binding of one of four endogenous tissue inhibitors of metalloproteinases (TIMPs). MMP-23 instead of hemopexin domain has unique cysteine-rich, proline-rich and IL-1 type
II receptor-like domains. MMP-14, MMP-15, MMP-16, and MMP-24 have also a transmembrane domain which anchors them to the cell membrane whereas MMP-17, and MMP25 have on their C-terminus a glycophosphatidyl inositol membrane anchoring signal [5].

Since excessive activity of MMPs might be detrimental to the tissue (as it happens under some pathological conditions), the enzyme gene expression, mRNA maturation, distribution and survival, as well as protein release and activation are all strictly regulated. This can be best described in the example of one of the most studied MMP, MMP-9 [8]. MMP-9 transcription is activity regulated by inducible transcription factors, such as AP-1 [9, 10], then MMP-9 mRNA transport, survival and translation are also activity regulated, as it has been demonstrated for neurons [11-13]. MMP-9 is present within cells in vesicles distributed along microtubules and microfilaments and is secreted in a Golgidependent pathway in 160-200 nm vesicles [14-16]. Notably, MMP-9 is often found in the same secretory vesicles as its inhibitor, TIMP-1 and although secreted upon stimulation, it is thought to act very focally and can be concentrated at the cell membrane by binding to cell adhesion molecules such as the hyaluronian receptor CD44 $[17,18]$ or integrins [19].

The activation of proMMP-9 occurs extracellularly after its release and is controlled by a cascade of steps involving other proteases, inhibitors and receptors. For example, serine proteases: tissue plasminogen activator (tPA) or urokinase plasminogen activator (UPA), which can be docked to the membrane by its receptor, uPAR, activate the conversion of plasminogen to plasmin, which in turn can activate proMMP-9 [20]. Additionally, some MMPs such as MMP11 or MMP-28 and all membrane-type MMPs (MT-MMPs) have also a furin-like recognition motif in their propeptide and can be thus activated inside the cell before secretion or exposure to cell surface, and activate other secreted MMPs [21]. Once activated, MMP-9 can be inhibited, particularly by TIMP-1, but also by other TIMPs [22]. This is because, similarly to redundancy in MMPs substrate specificity, there is a significant overlap in the affinity of TIMPs to different MMPs [8].

TIMP-1 can inhibit MMPs directly by binding through its $\mathrm{N}$-terminal domain to the catalytic site of the enzyme [23]. Interestingly, inhibition of MMP-9 can be also achieved by binding TIMP-1 C-terminus to the hemopexin domain of MMP-9, thus blocking its interaction with substrate or membrane docking proteins [24]. MMP-9 and TIMP-1 share the same release kinetics [25] and it has been shown that those two proteins can be co-released even from a single vesicle $[14,15,26]$. Moreover, it has been proposed by Ogata and co-workers [27] that TIMP-1 bound to MMP-9 via the hemopexin domain is also important during activation of the gelatinase by other MMPs, like MMP-3. Finally, activated 
MMP-9 binds through its hemopexin domain to low-density lipoprotein receptor-related protein, which is an endocytic receptor for this and many other proteins, and after endocytosis leads to the destruction of MMP-9 [28].

All the regulatory mechanisms, such as secretion, interaction with membrane receptors, internalization and TIMPdependent inhibition, are to limit spatially and temporarily MMP's activity outside the cell and prevent excessive, potentially pathological activity. An interesting example of physiological, tight control by TIMP-1 over MMP-9 has been recently published by Magnowska et al. [29], where both proteolytic activity of MMP-9 and its following inhibition by TIMP-1 were discovered to be necessary for synaptic plasticity (see below). Interestingly, activation of MMP-9 in the brain tissue can be achieved by the degradation of TIMP-1 by cathepsin B, a lysosomal enzyme, which upon stimulation can be released to extracellular space and activate MMP-9 [30, 31]. Another example of MMP activating cascade is that of MMP-2, as it requires the formation of tertiary complex with TIMP-2 and MT1-MMP [32]. TIMP-2 forms a link between dimerized MT1-MMP and the hemopexin domain of pro-MMP-2. This leads to cleavage of MMP-2 propeptide by MT1-MMP and thus its activation.

As already mentioned, MMPs are inhibited by four endogenous inhibitors, TIMP-1 to TIMP-4. They are all soluble and share a common structure, but their role is very diverse. For example, TIMP-1 can act independently to its inhibitory activity as a growth factor suppressor [33] or a cytokine [34]. The cytokine effect of TIMP-1, which results in inhibition of neurite outgrowth and increase in growth cone volume, is mediated through its internalization by LRP-1 [35, 36].

\section{Expression in the brain}

Among the MMPs, many have been shown to be expressed in the brain, namely: MMP-1, MMP-2, MMP-3, MMP-7, MMP-8, MMP-9, MMP-10, MMP-11, MMP-12, MMP13, MMP-14, MMP-15, MMP-16, MMP-17, MMP-24 and MMP-28. Notably, a number of those are expressed in the brain only under very particular physiological and/or pathological circumstances.

MMP-1 (collagenase 1) expression in the brain has often remained undetected [37, 38]. However, recent studies have shown MMP-1 immunoreactivity in the olfactory lobe, entorhinal cortex, pontine nuclei, and periaqueductal gray, but not in the hippocampus [39]. Moreover, MMP-1 protein level was increased at $4 \mathrm{~h}$ following systemic kainate administration [39] or after ischemic stroke [40], and was shown to be present in the brains of Alzheimer's disease patients [41]. MMP-1 seems to be mostly expressed by glia $[42,43]$, but there are also reports indicating its presence in neurons [39]. MMP-1 was also shown to enhance proliferation and increased differentiation towards neurons of hippocampal neural progenitor cells [44]. Moreover, MMP-1 overexpression in transgenic mice under GFAP gene promoter enhances dendritic complexity and causes deficits in learning and memory [42]. Literature suggests that MMP-1 in the brain acts mainly through activating protease activated receptor 1 (PAR1) [44], and thus increasing cytoplasmic $\mathrm{Ca}^{2+}$ concentration [42], as it was proven also in platelets [45]. Interestingly, PAR 1 was shown to be cleaved and activated by another collagenase which is also expressed in the brain, MMP-13, however, this relationship was studied in cardiac fibroblasts and cardiomyocytes [45].

MMP-2 (gelatinase A) is one of the two gelatinases most extensively studied in the brain. It is constitutively expressed mainly by astrocytes [46, 47], however, many studies find it to be localized also in some cortical, and cerebellar neurons, as well as in the hippocampus and nucleus accumbens (NAc) [46, 48-51]. MMP-2, like most of the MMPs in the brain, is expressed at much higher level during early postnatal development than during adulthood, reaching peak around day 4 after birth [48, 52]. MMP-2 expression can be induced under various pathological conditions (see below). In particular, reactive astrocytes show increased expression of MMP-2 [53]. MMP-2 in astrocytes is localized at the leading edge of processes, where it regulates actin cytoskeleton and thus affects cell migration [54].

MMP-3 (stromelysin 1) is, as many other MMPs, expressed during development in the central nervous system. Around embryonic day 15, it is expressed in most brain areas in rat, and in mouse it is found in neurons of the ventricular zone. In late prenatal period, MMP-3 is also expressed in mature oligodendrocytes [55]. Until postnatal day 10, MMP-3 is expressed by most cells of the cerebellar cortex, striatum and hippocampus and can be found in both neuronal and glial cells [55-57]. MMP-3 is also expressed during postnatal brain development in cerebellum, specifically in Purkinje cell somata and dendrites as well as in some granule cells $[51,58]$. In the adult brain, MMP-3 expression level is either very low or negligible [37, 59], but some studies report its expression in the hippocampus, especially during learning paradigms $[60,61]$. A recent study of Wiera et al. [57] shows that in the stratum radiatum of hippocampus, MMP-3 seems to be mainly expressed by astrocytes in a sparse punctate manner. MMP-3 has a very broad range of substrates in the brain. It was shown, for example, to cleave almost all components of perineuronal nets [53]. MMP-3 is upregulated in many brain pathologies, disrupting blood-brain barrier, causing neuroinflammation and apoptosis. In such conditions, it is expressed by injured neurons, oligodendrocytes, astrocytes and reactive microglia or invading macrophages $[62,63]$. Induction of MMP-3 expression depends on binding of NFkB to its gene 
promoter upon the release of inflammatory mediators, e.g., interleukin- $1 \beta$ caused by ischemia, traumatic brain injury (TBI) or infections [64]. In addition, MMP-3 acts itself as a signaling molecule and creates positive feedback for inflammatory response, as it causes activation of microglia and synthesis of cytokines, e.g., tumor necrosis factor- $\alpha$, interleukin-1 $\beta$, or interleukin-6 [65]. However MMP-3 was also shown to have beneficial effects during pathological states as it can cleave Fas ligand [66], can promote synaptogenesis [67] and is involved in remyelination [68].

MMP-7 (matrilysin) expression during development, as well as in the normal adult brain, is often described as negligible [59, 69-71]. Most reports that detect MMP-7 in normal brain conditions point to glia (most often microglia) as MMP-7 expressing cells [69, 72, 73]; although the issue of MMP-7 source in the brain has often not been addressed in various studies. Interestingly, Le and Friedman [74] reported a high level of MMP-7 in hippocampal neurons, which dropped after seizures induced with kainic acid. MMP-7 is, though, strongly upregulated during such pathological conditions in the brain as multiple sclerosis [73], experimental autoimmune encephalomyelitis [75], HIV dementia [76] or brain tumors [71]. Among the substrates of MMP-7 in the brain, the most prominent are pro-nerve growth factor (proNGF) [74, 77], SNAP-25 [78], the NR1 subunit of NMDA receptor [79] or myelin-associated glycoprotein [80].

MMP-9 (gelatinase B) is the most studied MMP in the brain, with its expression in naïve brain kept on a very low level. It is found in hippocampus, cerebellum and cerebral cortex $[46,47,51,52]$ and is predominantly expressed by neurons, but also by glia [15, 47]. MMP-9 expression is tightly regulated on different levels (see above) and it peaks during early development [48, 51, 52]. Even though MMP-9 levels in the adult brain are low, they are upregulated during neuronal increased activity/plasticity but also, as so many other MMPs in pathological situations (see below and for recent reviews: $[4,81]$ ). Most interestingly, MMP-9 activity, as well as its mRNA are present in the vicinity of synapses [11, 82-84].

MMP-14 (MT1-MMP) is most often studied in the brain in the context of gliomas, where it is highly expressed along other MMPs. Under pathological and inflammatory conditions, it has been found expressed by microglia [85]. MT1MMP is, however, expressed on a low level in the normal adult brain [37]. MT1-MMP in the hippocampus is predominantly localized in neuronal cell layer [86] and expression of MT1-MMP is elevated upon BDNF treatment in mixed neuronal cultures [87]. In retina, it is expressed in retinal ganglion cells as well as in Müller glia [88]. Interestingly, MT1-MMP expression increases in female hippocampus upon the presentation of novel odor [89].

MMP-24 (MT5-MMP) is expressed at relatively high levels in the adult brain, particularly in the cerebellum, but also hippocampus and olfactory bulb [90,91]. It can be found predominantly in neurons and its expression is increased during development regulating axonal growth and dendritic tree formation of Purkinje cells [91, 92].

\section{Synaptic plasticity, learning and memory: MMPs expression and function}

Brain plasticity refers to the capacity for structural and functional reorganization of the neural networks in response to external challenges. Beside learning and memory, which allow for adaptation to the changing environment, neuroplasticity is necessary to recover after disorders and injuries. Brain plasticity is manifested at many levels in the nervous system, ranging from molecular events, such as changes in gene expression, protein availability and function, to cellular physiology, to behavior. At the cellular level, the plasticity is supported by dynamic modifications in neural connectivity and excitability that are driven by molecular changes in synapses, entire neurons and glial cells.

Synapses are particularly prone to dynamic alterations, and thus believed to play a major role in the plasticity. Aberrant synaptic plasticity leads to many pathological conditions, e.g., epileptogenesis, drug addiction, autism spectrum disorders, schizophrenia or depression. Compensatory brain plasticity may reduce the detrimental effects of such pathologies as multiple sclerosis, Parkinson's disease, cognitive deterioration or Alzheimer's disease. Induction and maintenance of activity-dependent synaptic plasticity adaptations require a temporal and spatial control of a complex sequence of events that result in the modification of pre- and postsynaptic content, as well as remodeling of the entire tetrasynapse morphology.

Excitatory synapses that are particularly plastic, are predominantly located on small dendritic protrusions called spines, whose morphology can be taken as a proxy for the synaptic efficacy [93]. Small dendritic spines often harbor silent synapses, equipped with a limited number of NMDA receptors for glutamate and virtually missing AMPA receptors (AMPAR) for this excitatory neurotransmitter. Increased synaptic efficacy that may produce neuronal depolarization associates with the accumulation of AMPAR (and thus enhanced glutamate responsiveness) that in turn correlates with increased spine volume and enlargement of the dendritic spine head, producing spines with a mushroom shape.

MMPs have repeatedly been implicated in synaptic plasticity thanks to their capacity to act in a tightly controlled, short temporal window, targeting extracellular matrix, cell adhesion molecules, synaptic receptors, neurotrophins and other proteins implicated in synaptic efficacy and remodeling. Studies with broad spectrum MMPs inhibitors have demonstrated impairments in various short- and long-term 
plasticity models including paired pulse and theta burst facilitation, maintenance of long-term potentiation (LTP), induction and magnitude of long-term depression (LTD) in the hippocampus [94-96], as well as ocular dominance plasticity in the visual cortex and barrel cortex plasticity, resulting from sensory deprivation [97-99].

Recent studies have shed light on the role of MMPs in synaptic plasticity. In this regard, the best studied involvement of metalloproteinase function in synaptic plasticity processes concerns the activity of MMP-9. This issue has been covered by extensive reviews [4, 100-103], so it will be only briefly presented here.

MMP-9 is released from the postsynaptic compartment of excitatory synapses in an activity-dependent manner [11, 82]. Upon activation, MMP-9 cleaves (among others) such synaptic cell-adhesion molecules as: $\beta$-dystroglycan [104], neuroligin-1 [105], nectin-3 [106], intercellular adhesion molecule-5 (ICAM-5) [107, 108], synaptic cell adhesion molecule-2 and collapsin response mediator protein-2 [109], affecting NMDA receptors mobility and function at the synapse [110, 111]. Chemical LTP experiments on dissociated and organotypic hippocampal cultures revealed MMP-9-dependent spine enlargement, accumulation of AMPA receptors in the synapse and increase in the spike count and bursts frequency [84, 112-115]. Transient function of MMP-9 is a requirement for maintenance of the late phase, NMDAdependent LTP at various pathways in the hippocampus [116-119], prefrontal cortex (PFC) [120], as well as basal and central nuclei of the amygdalar complex [121]. Furthermore, Dziembowska et al. [11] reported increases in MMP-9 mRNA levels in the hippocampal dentate gyrus of rats with LTP evoked therein by the perforant path stimulation.

The increase of limited MMP-9 activity at the synapse has a profound impact on synaptic morphology. It was reported that activation of this metalloproteinase during LTP induction leads to the enlargement of dendritic spines [118]. This, actually, is a two-step process that begins with the MMP9-mediated elongation of dendritic spines into apparently more immature, filopodium-like shape [122-124]. Then, only upon inhibition of the proteolytic activity, which in neurons might be mediated via specific inhibitor TIMP-1 $[46,125]$, dendritic spines assume larger, mushroom-like shape [29].

As far as learning and memory are concerned, MMP-9 activity was reported to be increased after Morris water maze, head-shake response, passive avoidance and appetitive learning $[60,61,116,126]$. Importantly, in addition to the functional role of MMP-9 in activity-dependent synaptic remodeling, blocking the enzyme has dramatic consequences on learning processes in vivo. Using either pharmacological inhibition or genetic ablation, it was demonstrated that MMP-9 activity was necessary for hippocampus-dependent learning, as shown in Morris water maze, contextual fear conditioning and reconsolidation of fear memory [60, 117, $127,128]$, as well as amygdala-dependent positive reinforcement conditioning in sucrose preference task [126]. On the other hand, fear conditioning to an auditory cue, as well as avoidance learning of an exposure to an air-puff or a bitter taste in the Intellicages, remained undisturbed in MMP-9 KO mice $[117,126]$. Of note, LTP to lateral nucleus of the amygdala is believed to support the aversive learning, such as aforementioned fear conditioning to an auditory cue [121]. Therefore, lack of MMP-9 requirement in the aversive learning might be explained by the fact that the enzyme is not obligatory for the lateral amygdala synaptic plasticity and LTP.

Interestingly, MMP-9 has also been considered as a player in human cognition. In the study of Bach et al. [129], blocking the activity of MMP-9 by administration of its inhibitor doxycycline $3.5 \mathrm{~h}$ prior to the fear conditioning procedure, reduced the fear response in human subjects measured 1 week after the test. This might suggest that lower MMP-9 activity during fear acquisition phase attenuated the formation of the fear memory. Moreover, reduced mRNA and protein levels of MMP-2, MMP-9 and TIMP-2 were observed in patients diagnosed with depression and displaying lower performance in cognitive tasks, as compared to healthy subjects [130]. Furthermore, within the healthy control group, there was a positive correlation between MMP-2 (protein level), MMP-9 and TIMP-2 (mRNA levels) and performance in cognitive tasks: visuospatial performance, working memory tasks, auditory-verbal memory, the effectiveness of learning processes and verbal fluency [130]. Similar positive correlation between MMP-9 serum level and decision-making abilities was observed in bulimia nervosa patients [131]. Another report on MMP-9 involvement in cognition comes from a study on male bipolar patients. Those subjects carrying a $M M P 9$ gene polymorphism $-1562 \mathrm{C} / \mathrm{C}$, apparently characterized with lower promoter activity, performed better in cognitive tests than people with other genotypes [132]. It should be, however, noted that recent study by Gregory et al. [133] has questioned the role of this gene polymorphism in regulating MMP-9 expression in the brain and, furthermore, has demonstrated the gene polymorphism affects the brain structure and function that obviously may contribute to cognition.

MMP-3 role in learning and memory is best described in hippocampus-dependent learning tasks. In a spatial memory test-the Morris water maze-it was reported that MMP-3 mRNA and protein levels were elevated during the acquisition phase, while pharmacological inhibition of MMP- 3 activity disrupted this learning process $[60$, 128]. The increase of MMP-3 level in this spatial learning task was prevented by the blocking of the NMDA receptor with the MK-801 antagonist $[60,128]$. Similarly to spatial learning, a passive avoidance test revealed an increase of 
MMP-3 protein level in the hippocampus within a few hours post training, suggesting the role of MMP-3-induced ECM remodeling in associative memory consolidation [134]. Habituation increases MMP-3 expression in hippocampus and PFC [135], while injection of MMP-3 inhibitor into the hippocampus interferes with this task [136].

Looking closer into cellular mechanisms of MMP-3 action in the hippocampus, it was reported that, similarly to MMP-9, a transient activation of MMP-3 (within $30 \mathrm{~min}$ window post stimulation) is necessary for synaptic potentiation, described in the excitatory postsynaptic potential (EPSP)-to-spike potentiation phenomenon-a long-term potentiation of synaptic inputs [137]. EPSP-to-spike potentiation is a NMDA receptor-dependent process and the timing of MMP-3 activation overlaps with the short window of NMDARs activity requirement to prolong the potentiation [137, 138]. MMP-3 has been shown to cleave NR1 subunit of NMDA receptors in in vitro neuronal cultures, therefore, it could affect synaptic NMDARs function, necessary during plastic adaptations [139]. Moreover, MMP-3 can affect synaptic efficacy by mediating the structural plasticity of dendritic spines. As reported in the visual cortex of MMP-3 KO mice, the morphology of dendritic spines was impaired, namely, the higher number of short, mature spines perturbed open-eye potentiation in visual cortex of these knockout mice [140].

Similarly to MMP-3, MMP-7 has also been shown to affect spine morphology in a NMDAR-dependent manner. In cultured hippocampal neurons, application of recombinant MMP-7 induced a robust reorganization of spines, changing mushroom-shaped spines into filopodial type. This effect was triggered by rapid $\mathrm{F}$-actin reorganization (observed after 10-20 min) and was dependent on NMDAR function (blocked by MK-801) [122]. In fact, in acute cortical slices, MMP-7 cleaved NR1 and NR2A subunits of NMDARs. This caused a reduction in NMDA-induced $\mathrm{Ca}^{2+}$ influx [79]. Therefore, MMP-7 may directly affect NMDARs function and its downstream signaling, pivotal for synaptic plasticity. Moreover, in the presynaptic terminus, application of recombinant MMP-7 on cultured hippocampal neurons decreased the readily releasable pool of synaptic vesicles, decreased the size of active zones and inhibited vesicle recycling [78]. MMP-7 effects on vesicle recycling could be partially explained by its cleavage of the SAP- 25 protein (synaptosomal-associated protein of $25 \mathrm{kDa}$ ), which disrupts the vesicle docking complex [78].

Among MT-MMPs involved in synaptic functions in the brain, MT5-MMP (MMP-24) is the best characterized. In comparison to other MMPs, it is highly expressed in the brain and it is present at the synapses thanks to binding to AMPA receptor binding protein (ABP), and glutamate receptor interacting protein (GRIP) [141]. Monea and co-workers [141] have also identified N-cadherins as
MT5-MMP substrates, which further implies the important function of this MMP at the synapse. Additionally, MT5MMP is capable of cleaving $\beta$-amyloid precursor protein (APP) creating carboxy-terminal fragments of APP, which are able to impair hippocampal LTP as well as reduce neuronal activity in vivo [142]. In a study of traumatic brain injury (TBI) MT5-MMP protein level was increased during synaptic remodeling after the injury and blocking MMPs activity restored levels of $\mathrm{N}$-cadherin and partially restored LTP induction [143]. In those experiments MT5-MMP was, however, expressed mainly in reactive astrocytes and applications of GM 6001, a broad spectrum MMP inhibitor, could not exclude the involvement of other MMPs in this process.

\section{MMPs in epilepsy and epileptogenesis}

Epilepsy is a brain disorder characterized by an enduring predisposition to generate epileptic seizures and by the neurobiological, cognitive, psychological and social consequences of this condition. It is also manifested in the structural changes observed in epileptic brain, such as neuronal reorganization, especially prominent within hippocampus, including axonal sprouting.

In fact, epilepsy is not a homogenous disorder, but rather a collection of subtypes with a variety of etiologies. Thus, epilepsies are divided based on the underlying etiology into: (1) genetic, which are caused by genetic factors; (2) structural/metabolic, which have distinct structural or metabolic conditions, including acquired epilepsies caused by stroke or brain trauma; and, (3) of unknown cause [144, 145]. Acquired epilepsies constitute about $30 \%$ of all cases of epilepsy and are most commonly caused by stroke, brain trauma, alcohol use, neurodegenerative diseases, or infection [146]. In acquired epilepsies, brain-damaging insult leads to epileptogenesis (latency period without seizure) lasting up to several years that culminates in the appearance of seizures and epilepsy diagnosis.

Among epilepsy types with not well-defined genetic causes, particularly common are temporal lobe epilepsy (TLE) and post-traumatic epilepsy (PTE). TLE is the most frequent and drug-resistant type of adult focal epilepsy, characterized by the appearance of epileptic foci in such temporal lobe structures as hippocampus or amygdala [147-149]. PTE develops often as a result of TBI caused by an external mechanical force. This initial brain insult triggers a cascade of events called epileptogenesis that can last in humans for years and that finally leads to the appearance of spontaneous recurring seizures (epilepsy) [150].

There are several mechanisms by which MMPs may participate in epileptogenesis and epilepsy, including blood-brain barrier breakdown, and contributions to inflammatory reactions and synaptic plasticity. The best examined 
proteinase with a significant role in different models and types of epilepsy appears to be MMP-9 [4, 151].

Zhang et al. [152, 153] were the first to report that MMP-9 level (as well as MMP-2) increased in a brain region- and age-related manner in rats subjected to proconvulsive treatment with kainic acid (KA) — a well-recognized model of TLE. Similar increases were also observed after treatment with bicuculline $\left(\mathrm{GABA}_{\mathrm{A}}\right.$ receptor antagonist, provoking seizures). Next, Szklarczyk et al. [47] demonstrated that MMP-9 expression-at the levels of mRNA, protein and enzymatic activity-was markedly upregulated by KA. Of particular interest was surprising finding that those responses were limited to the dentate gyrus, i.e., the hippocampal region undergoing the most extensive postKA plasticity, presumably supporting epileptogenesis. Then, Wilczynski et al. [154] directly investigated the role of MMP-9 in two animal models of epileptogenesis, namely, KA-evoked status epilepticus (SE, a condition known to provoke the development of epilepsy) and proconvulsive pentylenetetrazole (PTZ, a $\mathrm{GABA}_{\mathrm{A}}$ receptor antagonist) chemical kindling. They showed that the sensitivity to PTZ kindling was decreased in MMP-9 knockout mice but was increased in transgenic rats with neuronal overexpression of MMP-9. Furthermore, Wilczynski et al. [154] demonstrated that MMP-9 deficiency diminished KA-evoked pruning of dendritic spines and decreased aberrant synaptogenesis after mossy fiber sprouting. Finally, they also reported that MMP-9 was associated with excitatory synapses, where both MMP-9 protein levels and enzymatic activity become strongly increased upon seizures. Subsequently, the presumed role of MMP-9 in epileptogenesis was confirmed by Mizoguchi et al. [155], who showed enhanced MMP-9 activity and expression in the injured hippocampus in PTZ kindling model. The role of MMP-9 in the development of epilepsy has been also supported by studies with such models of epilepsy as treatment with either pilocarpine or 4-aminopyridine (seizure-inducing drugs), as well as the use of Wistar Albino Glaxo Rijswijk (WAG/Rij) rats that display higher propensity for seizure activity [156, 157].

PTE is a life-long complication of TBI [158], where seizures are provoked by head injury. Little is known about the mechanisms that lead to post-injury epilepsy development. Based on data from experimental models and human tissue, epilepsy resulting from head injury is associated with various morphological and physiological changes, such as neurodegeneration, myelin and axonal injury, axonal and synaptic plasticity, changes in spine density/morphology, neurogenesis, gliosis, blood-brain-barrier damage, angiogenesis, changes in extracellular matrix and molecular reorganization of ion channels in individual neurons.

It has been reported that in fluid percussion injury (FPI) and controlled cortical impact (CCI) models of TBI, tissue level of mRNA and active form of MMP-9 protein, were increased in ipsilateral cortex and hippocampus after injury [159-162]. This increase was observed during the firstweek post-injury $[163,164]$. Besides the upregulation of MMP-9, time-dependent increase of its inhibitor, TIMP-1 mRNA has been observed in ipsilateral cortical areas [165]. Unbalance between MMP-9 and TIMP-1 as a result of insult, could induce various structural, cellular and neurochemical changes, such as mossy fiber sprouting, synaptogenesis, changes in expression of $\beta$-dystroglycan, BDNF, integrins as well as cell death or neurogenesis. These processes could lead to increased excitability and changes in neuronal circuitry [166]. The possible role of MMP-9 in post-TBI consequences was confirmed by finding that MMP-9 KO mice displayed less prominent motor deficits and significantly smaller post-TBI lesion volumes than wild-type siblings [164]. Recently, Pijet et al. [167] have demonstrated that PTE occurrence is correlated with the size of the lesion upon injury, where the high level of MMP-9 characterized by a large lesion area, predisposes to PTE development, while inhibition of MMP-9, with small lesion volume, protects from PTE. Pijet et al. [167] have also shown that MMP-9 deficiency decreased the seizure appearance in a PTE model, whereas overexpression of MMP-9 increased the likelihood of spontaneous seizures.

The contribution of MMP-9 to epileptogenesis has further been substantiated by the use of MMP-9 inhibitors. It has been shown that inhibitors of MMP-9 used in status epilepticus animal model, reduced neuronal cell death [156, 168, 169], modified the inflammatory response by suppression of pro-inflammatory cytokines in microglial cells [63]. Finally, inhibition of dendritic spines morphological reorganization and severity of seizures induced in kindling model has been observed by Yeghiazaryan et al. [170], who proved the supposition that pharmacological inhibition of MMPs might be beneficial by suppressing seizure progression in animal models of epilepsy [168, 171].

In addition, in humans with different types of epilepsy, the occurrence of the seizures is correlated with the elevated levels of MMP-9 in serum or plasma as well as in the cerebrospinal fluid [172-175]. Similarly, the ratio of MMP-9 to TIMP-1 was increased under epileptic conditions [175]. It has been speculated that this phenomenon can promote brain blood barrier damage [176], which is correlated with elevated expression of MMP-9 in serum [177]. Moreover, studies made on brain surgery tissue revealed increase in MMP-9 level in epileptogenic lesions associated with epileptic conditions such as focal cortical dysplasia (FCD), tuberous sclerosis or TLE [178-182]. Interestingly, in children with intractable and non-intractable epilepsy, salivary MMP-9 concentration was decreased compared to controls [183]. Zybura-Broda et al. [182] have investigated epigenetic changes on the $M M P 9$ gene promoter, finding an increased DNA demethylation in human epileptic tissue as compared 
to control brain tissue. Notably, the authors have also demonstrated that progressive $\mathrm{Mmp} 9$ gene promoter demethylation accompanied the development of seizure susceptibility in PTZ kindled rats.

The role of other MMPs in epilepsy development appears poorly investigated. An expression of MMP-2 in epileptogenesis process has often been examined simultaneously with MMP-9. Delayed increase in MMP-2 activity was observed in animal models of TLE after systemic injection of pilocarpine [168] or kainic acid [152, 153]. The increase of MMP-2 was less pronounced compared to MMP-9, nevertheless being significant. However, as so far, there is no further data describing the involvement of MMP-2 in epilepsy development. MMP-2 may increase the permeability of the blood-brain barrier which encourage seizures appearance and facilitates epilepsy development [184]. Interestingly, MMP-2 serum levels in patients with epilepsy were significantly lower [185].

In the kainic acid model of TLE, MMP-3 expression was found to be increased [186, 187]. Moreover, in response to TBI, both hippocampal and CSF levels of MMP-3 were elevated $[65,188]$. In contrast, serum MMP-3 levels in epileptic patients was found to be decreased [185]. Elevated expression of hippocampal MMP-3 mRNA and protein after TBI as well as SE was also reported [67, 159, 189]. Gorter et al. [62] also demonstrated an enhancement in the expression of MMP-2 and MMP-14 induced by SE evoked by electrical stimulation of the hippocampus.

Using an unbiased approach of antibody microarrays, Konopka et al. [179] found an elevated expression of MMP$1,-2,-8,-10$, and -13 , in addition to MMP-9, in the epileptic brain tissue from patients with FCD. However, the expression of these proteinases was not as pronounced and/or not as consistent among patients as the expression of MMP9. Among these other MMPs, especially striking was the upregulation of MMP-2 in adult patients only, but the significance of this finding is presently unclear.

\section{MMPs in mental disorders: focus on autism spectrum disorders, fragile $X$ syndrome, schizophrenia, bipolar disorder, chronic stress and major depression}

Mental health is as a state of well-being that enables individuals to realize their abilities, deal with the normal stresses of life and work productively [190]. Mental health disorders appear when the homeostasis is lost and abnormalities in thoughts, perceptions, emotions, behavior and relationships with others appear [191]. The rise in number of people suffering from mental disorders makes them a topic of considerable and growing research interest [190]. Importantly, the neuropsychiatric disorders often share comorbidities, hence it may seem difficult to draw a hard line between particular medical conditions [192]. Therefore, it is legitimate to consider that for this reason they also share some aspects of underlying, including molecular, mechanisms. For the purpose of the present review, we shall focus on stress, major depression, bipolar disorder, autism spectrum and schizophrenia- the most common neuropsychiatric disorders. These diseases pose particular research challenges, as they are all difficult to model in experimental animals. In fact, the animal studies usually focus on reproducing and investigating only selective disease symptoms. Fortunately, the very intense effort on human genomics and proteomics has resulted in revealing major categories of possible molecular players underlying the neuropsychiatric conditions. Those categories are often overlapping among those conditions, with the major ones being: inflammatory/immune responses, epigenetics and gene regulation, and finally synaptic plasticity. Considering the fact that MMPs may fall into both inflammatory/immune category and synaptic plasticity and, as it has been well documented for MMP-9 in the brain, may be under very tight, including epigenetic, gene regulation (see above), there is no surprise that MMPs have been implicated, especially MMP-9, by virtue of gene associations and/ or protein levels, in neuropsychiatric disorders.

\section{MMPs in stress and depression}

Evolutionarily, stress is a response of the organism to a challenge or threat. When working properly in normal life it helps to maintain balance, and in an emergency situation, to survive. A chronic stress, however, is like a continuous emergency mode that can rewire the brain, so it becomes more vulnerable to anxiety or even a major depression (MD) and other health problems.

\section{Human data}

MMP9 - $1562 \mathrm{C} / \mathrm{T}(\mathrm{C} 1562 \mathrm{~T})$ gene promoter polymorphism is considered as functional, since a $\mathrm{C}$ to $\mathrm{T}$ substitution results apparently in a loss of binding of a nuclear silencer protein to this region of the $M M P 9$ gene to produce an increase in transcriptional activity [193]. This polymorphism has been found to be associated with depression, with the $\mathrm{C} / \mathrm{C}$ genotype or $\mathrm{C}$ allele increasing the risk of susceptibility to middle age depression and the $\mathrm{T}$ allele, on the other, hand reducing the risk [194]. The same study also found that in subjects bearing another $M M P 9$ gene polymorphism of unknown functionality, namely, $-1702 \mathrm{~T} / \mathrm{A}$, the T/T genotype or T allele led to increase in risk of recurring depressive disorder, whereas the A/A allele led to lower risks. As far as other MMPs are concerned, analysis of MMP7 -181 A/G gene polymorphism revealed its strong association with higher 
incidence of recurring depressive disorder. This research also pointed that dual occurrence of C/T C-735T/MMP2/ genotype and G/G A-181G/MMP7/genotype, and, C/T-T/T genotypes of the MMP2C-735T and MMP9T-1702A polymorphisms, were also associated with increased risks of recurrent depression [194].

Expression analysis of MMPs revealed that MMP-9 was upregulated in serum upon two stressful stimuli (recall of either an event that frustrated the patient or a mental arithmetic task) in patients with coronary disease [195]. In another study, an increased level of MMP-9 was found in the blood of patients with major depression [196]. MMP-9 levels were also correlated with the severity of depression and the quality of life of the patients [197]. MMP-9 levels were also found associated with several psychological factors linked with depression in a middle-aged population [198]. Another interesting observation was that in patients receiving electro convulsive therapy (ECT) as a treatment for depression, the serum levels of MMP-9 decreased significantly in those patients who did not show relapse of depression [199]. Interestingly, transcript and protein levels of MMP-2, MMP-9 and TIMP-2 were found to be downregulated in patients with the recurrent depressive disorder as compared to healthy individuals [130]. Finally, both mRNA and protein levels of several MMPs (MMP2, MMP-7 and MMP-9) were demonstrated to be higher in patients with $\mathrm{MD}$, when compared to healthy controls [200].

\section{Animal experiments}

In an animal model of prolonged stress (restrain of a mouse for $6 \mathrm{~h}$ per day, repeated for 21 days) that may contribute to depression, proteolytic activity of MMP-9 was shown to be enhanced in CA1 but not in CA3 of the hippocampus [106]. This result correlated with impaired social interactions that were reinstated following infusion of MMP inhibitor into the hippocampus [106]. Furthermore, Aguayo et al. [201] have found that a single stress exposure ( 2.5 or $24 \mathrm{~h}$ restrain) increases MMP-9 levels and activity in the hippocampus.

\section{MMPs in autism spectrum disorders and fragile $X$ syndrome}

Autism spectrum disorders (ASD) are considered to be neurodevelopmental disorders that affect communication and behavior. They are classified as a "spectrum" as there is varied range of manifestation of the phenotype [202].

\section{Human data}

Probably the most extensively studied genetic alteration linked to ASD concerns FMRI, encoding fragile X mental retardation protein (FMRP) [203]. Missing FMRP produces fragile X syndrome (FXS). Most interestingly, MMP-9 was found to be upregulated in the serum of patients with FXS, and, moreover, minocycline treatment that decreased MMP-9 levels led to clinical improvements in the patients [204-207]. In parallel, Janusz et al. [83] have demonstrated that FMRP controls local, dendritic/synaptic translation of MMP-9 and then Gkogkas et al. [208] using post mortem brains from FXS patients showed that phosphorylation of the mRNA $5^{\prime}$ cap binding protein, eukaryotic initiation factor 4E (eIF4E), was elevated concomitantly with increased expression of MMP-9 protein. More generally, the analysis of amniotic fluid in patients with ASD showed elevated levels of MMP-9 [209]. Increased MMP-9 was also found in postmortem cortex of ASD patients [210].

\section{Animal experiments}

There are several lines of evidence linking MMP-9 to FXS. This syndrome is well modeled in mice by the knockout (KO) of the FMRP encoding gene ( Fmrl). In fact, the first link between FXS and MMP-9 was revealed by Bilousova et al. [211], who reported increased MMP-9 activity in cultured neurons from Fmr1 KO mice and, furthermore, the disease phenotype of elongated dendritic spines could be rescued by minocycline inhibiting MMP-9 activity. Similarly, another group also showed that inhibiting MMP-9 could rescue the abnormal spine dynamics noted in Fmr1 KO mice [212]. Most interestingly, genetic removal of MMP-9 rescued the ASD-like symptoms of Fragile X in Fmr1 KO mice [213]. In another study, where abnormally high level of MMP-9 was observed in the auditory cortex of Fmr1 KO mice, genetic deletion of MMP-9 was able to rescue habituation deficits [214].

Furthermore, pharmacological inhibition of elF4E dependent MMP-9 translation (see above) has been able to reverse symptoms of Fragile X in Fmr1 KO mice [208]. In addition, the drug minocycline was able to lower MMP-9 levels in Fmr1 knockout mice, reduced anxiety and rescued Fragile X such as phenotype [215]. Interestingly, metformin, a drug used for treating diabetes, has been shown to normalize elF4E phosphorylation and MMP-9 gene expression, and subsequently rescue the core phenotypes of Fmr1 hemizygous mice [216].

Perineuronal nets (PNN) are assemblies of the extracellular matrix, which cover the interneurons expressing parvalbumin. Abnormalities in PNN have been reported in schizophrenia and Alzheimer's disease. MMP-9 is considered as a PNN regulator and thus alterations in its levels might result in PNN abnormalities [217]. In fact, genetic reduction of MMP-9 levels to wild-type equivalence in Fmr1 KO mice led to the restoration of PNN formation around parvalbumin 
cells in the auditory cortex and rescued altered sound-driven response phenotype in these mice [217].

ASD-like-phenotype had also been reported in zinc transporter 3 (ZnT3) KO mice along with increased MMP-9 and BDNF levels-possibly due to perturbed zinc homeostasis. Treatment of these mice with minocycline rescued ASDlike-phenotype and reduced BDNF levels [218].

Notably, it has been suggested that MMP-9 might serve as a very promising target for drugs to treat ASD and FXS patients [219].

\section{MMPs in schizophrenia and bipolar disorder}

Schizophrenia is a neuropsychiatric disorder affecting $0.5 \%$ of the human population [220]. The disease is characterized by heterogeneous display of positive symptoms (hallucinations, delusions, and thought disorder), negative symptoms (avolition, restricted affect, poverty of speech, and social withdrawal), and cognitive dysfunction (working memory deficits, executive function, and attentional dysfunction). Schizophrenia onset occurs typically in early adulthood and is usually associated with a lifetime disability. Bipolar disorder (BD) is a major mental disorder with a high risk of suicide [221]. BD onset occurs in adolescence [222]. The disorder is characterized by mania episodes followed by depressive ones [222]. Of note, even though bipolar disorder and schizophrenia are typically considered to be separate diseases entities, in some cases it is difficult to provide a clear separation and these two conditions may be considered as a schizoaffective disorder [223].

\section{Human data}

MMP9 $\mathrm{C} 1562 \mathrm{~T}$ gene promoter polymorphism has been shown to associate with schizophrenia [224, 225]. An interesting example of gene-schizophrenia association is rs20544 $\mathrm{C} / \mathrm{T}$ SNP that has been demonstrated to be strongly linked to the disease delusional symptoms [226]. This polymorphism is located within MMP9 $3^{\prime} \mathrm{UTR}$ mRNA and the authors have also shown that it affects RNA structure and binding to FMRP as well as synaptic MMP-9 availability and morphology of dendritic spines [226]. The polymorphism linked to lower MMP-9 synaptic release has been associated with more severe delusional symptoms [226]. Recently, Gregor et al. [227] have shown that the effects of anti-psychotic treatment, as well as the severity of childhood trauma are highly dependent on the type of MMP-9 gene variations. Thus, the SNP rs13925 was found to result in a reduced risk of developing treatment refractory schizophrenia, particularly in the presence of homozygous recessive genotype [227].
As far as MMP3 is concerned its $-11715 \mathrm{~A} / 6 \mathrm{~A}$ (rs3025058) polymorphism has been associated with schizophrenia [228]. In this study in Turkish population, it was found that the $6 \mathrm{~A} / 6 \mathrm{~A}$ and $6 \mathrm{~A}$ allele frequency was less in patients with schizophrenia, whereas the $5 \mathrm{~A} / 5 \mathrm{~A}$ and $5 \mathrm{~A}$ allele frequency was more.

Measuring the transcript and protein levels of MMPs in schizophrenia has also yielded interesting results. Ali et al. [229] reported that in spite of not finding any correlation between MMP9 $-1562 \mathrm{C}>\mathrm{T}$ SNP and schizophrenia, the levels of MMP-9 were found to be upregulated in serum of schizophrenic patients. An unbiased approach in screening altered levels of plasma proteins in patients with schizophrenia also revealed increased levels of MMP-9 and TIMP-1 [196]. Rahimi et al. [230] showed that there were no significant differences in the individual levels of MMP-9 and TIMP-1 genes in schizophrenia patients, but the MMP-9/ TIMP-1 ratio was significantly altered (see also Ref. [231]). Similarly, upregulated MMP-9 serum levels were found to be strongly associated with levels of mature BDNF (MMP-9 aids in the formation of mature BDNF from pro-BDNF) in schizophrenia patients [232]. Another independent study confirmed increased MMP-9 activity in the blood of schizophrenia patients [233]. Increased MMP-9 serum levels were likewise found to be correlated to oxidative stress in schizophrenia cases [234]. Similarly, MMP-9 gene expression in blood mononuclear cells was found to be upregulated in schizophrenia patients who did not undergo treatment. Interestingly, the levels were no longer significantly different after the administration of the treatment [235].

As in schizophrenia, polymorphisms and changes in the levels of MMPs have been associated with BD. Rybakowski et al. [236] originally demonstrated that C1562T MMP9 polymorphism linked to $\mathrm{BD}$. It was also found that the serum levels of MMP-9 were upregulated in patients with BD both during the acute phase and remission of depression [237]. Sodersten et al. [238] observed no differences in the level of MMP-9 in patients with BD but found that its levels correlated positively and significantly with mature BDNF levels, what shall be considered in a context of findings suggesting that MMP-9 may cleave pro-BDNF to its mature form.

As far as $M M P 10$ is concerned, individuals suffering from BD with T/T allele of MMP10 rs486055 (C/T R53K) polymorphism, were reported to have more depressive events than with $\mathrm{C} / \mathrm{T}$ or $\mathrm{C} / \mathrm{C}$ alleles [239]. Interestingly MMP-7 levels were also shown to be elevated in patients with $\mathrm{BD}$ [240, 241].

\section{Animal experiments}

Clearly, the cognitive symptoms of schizophrenia appear the easiest to model in animals by studying learning and memory phenomena, which, however, might lead to great 
oversimplifications. Nevertheless, in this context, it is worthy to recall the aforementioned data linking MMP-9 levels to learning and memory functions (see above). In addition, negative symptoms of the disease are apparently relatively easy to model, however, to dissect those from depressive behaviors might be difficult. The positive symptoms of schizophrenia can be modelled by enhanced hyperlocomotor response to such NMDA receptors antagonists as MK-801. Lepeta et al. [226] demonstrated that MMP-9 heterozygous mice display such enhanced hyperlocomotor response to MK-801, thus, this result was in line with the aforementioned clinical data on MMP-9 3'UTR mRNA polymorphism causing lower synaptic MMP-9 levels and linked to enhanced delusional symptoms of the disease [226].

\section{MMPs in addiction: alcohol, cocaine, methamphetamine, nicotine}

Addiction is a condition characterized by compulsive drug use, seeking and other related behaviors, despite knowledge of the negative consequences [242]. Even though in many cases substance use is the most common type of addiction, a person is capable of developing an addiction also to other rewarding behaviors, such as gambling, game playing or internet as well [243]. Exposure to addictive substances has been shown to create long-lasting alterations in brain function [244]. These take place in brain areas and in neuronal circuits involved in appetitive reward learning and memory formation [245]. The overlap between molecular processes involved in the former and pharmacological actions of drugs suggest that the key proteins driving learning and memory are also important players in the formation of addiction.

The role of MMPs in addiction has recently been reviewed [4, 246]. One of the best described MMPs in the context of addiction is MMP-9. Data from human studies indicate that its levels are increased in the hippocampus of cocaine [247], heroin [248] and alcohol abusers [249]. Furthermore, MMP-9 mRNA level is increased in methamphetamine addicts [250]. Moreover, in alcohol abusers, polymorphism of the MMP-9 gene producing higher protein expression is more frequent in alcoholics' families than in control subjects' families [251]. Animal studies revealed the involvement of MMPs in addiction to morphine [252], methamphetamine [76, 253, 254], nicotine [255], ethanol [256-258], cocaine [50, 259, 260] and heroin [50].

MMPs are activated and play functional roles in such particular aspects of addiction, as motivation in mice and human subjects [257], rewarding effect [254, 261, 262] or relapse/reinstatement in rats $[50,255,259]$. Animals devoid of MMP-9 drink as much alcohol as wild-type animals, yet they are impaired in alcohol seeking when access to ethanol is limited (withdrawal) or requires additional effort to obtain it (motivation) [257]. Similar alterations were also observed in MMP-2 and MMP-9 deficient mice, which subjected to methamphetamine treatment did not develop sensitization towards this drug [254].

Some reports indicate that metalloproteinase inhibitors can reduce behavioral correlates of addiction. MMP-2 and MMP-9 inhibitors reduced sensitization and blocked in mice methamphetamine conditioned place preference (CPP), i.e. rewarding effect of drug manifested by time spent in drug-associated chamber [261, 262]. When infused prior to cocaine administration, a broad spectrum MMP inhibitor blocked acquisition of CPP and reduced its reinstatement after a cocaine-priming injection in rats that underwent CPP extinction [259]. The same inhibitor, when injected intracerebroventricularly to rats exposed to long-term alcohol vapor self-administration prevented the escalation of alcohol vapor intake during acute withdrawal [256]. Similarly, in heroin addiction, MMP inhibition attenuates heroin cue-induced seeking [263]. Not surprisingly then, restoring the availability of MMPs reverses these effects, as overexpressing the active form of MMP-9 in the amygdala increased mice motivation towards ethanol selfadministration [257].

As far as the structural and functional plasticity is concerned, Smith et al. [50] discovered that extinction and reinstatement of cocaine self-administration causes an increase in spine density, together with the enlargement of spine heads in neurons of the nucleus accumbens, a structure particularly involved in execution of motivated behaviors and addiction [264]. This morphological remodeling is associated with MMP-2 and MMP-9 activities and causes strengthening of glutamatergic synapses, measured by the increase in AMPA/ NMDA receptors currents ratio. Our studies in the central amygdala, on the other hand, show that high motivation to ethanol self-administration is associated with the enlargement of long and mushroom spines [257]. This effect is not observed in MMP-9 KO mice. Moreover, ethanol consumption and subsequent withdrawal change synaptic efficacy by the formation of silent synapses and the reduction of AMPA/NMDA receptors currents ratio. Silent synapses are immature synaptic connections, which appearance signifies enhanced plasticity [265]. They are strongly involved in cocaine and morphine addiction [266, 267]. Our observations that MMP-9 activity causes an increase in silent synapse number [29], while genetic ablation of MMP-9 prevents their formation [257], indicate that the function of this gelatinase is particularly significant in the remodeling of synaptic efficacy.

\section{Concluding remarks}

Whereas traditionally, MMPs in the brain used to be considered as enzymes chiefly contributing to a pathological neuronal cell loss occurring in such disorders as various forms 
of neurodegeneration, stroke, traumatic brain injury, multiple sclerosis, gliomas, etc., the present review offers another look at the brain MMPs. It has been well documented that these enzymes, with MMP-9 serving as a most prominent example (maybe merely because of being the most extensively studied), contribute to learning and memory, as well as such major neuropsychiatric conditions as epilepsy (its development, i.e., epileptogenesis, in particular), schizophrenia, autism spectrum (with particularly strong example of fragile $\mathrm{X}$ syndrome), and addiction to various substances of abuse (including alcohol, cocaine, and others), depression, etc. Physiological and pathological synaptic plasticity emerges as a common theme, as far as the mechanisms of all those conditions are concerned. Indeed, the evidence for pivotal role of some MMPs, again MMP-9 in particular, in functional and morphological, physiological and aberrant plasticity of excitatory synapses appears very convincing. The fact that MMP-9 might be locally produced and released at/around those synapses provides further support for this notion. On the other hand, MMPs might be also produced and released by glia and brain-invading leukocytes, fueling a neuroinflammation. To dissect those various activities (including mutual interactions, e.g., during the activationcleaving off the propeptide-step) of MMPs, their specific expression patterns (cellular origins and time-courses) poses the major research challenge. Addressing this challenge shall advance not only our understanding of the brain in health and disease but may be expected to lead to novel, important disease biomarkers and diagnoses and even new therapies aiming at either inhibiting the enzymes or augmenting their activities. One should not overlook in this context the apparent regulatory and signaling functions of MMPs, their enzymatic nature (particularly amenable for manipulation) and finally, extracellular locus operandi. It has to be finally noted that overlapping substrate specificity of various MMPs poses a great challenge by itself, as far as the development of specific enzyme inhibitors is concerned.

Acknowledgements The research in Kaczmarek laboratory is supported by the BRAINCITY program, funded by Foundation for Polish Science and financed by the European Union Smart Development Operational Programme [BRAINCITY (MAB/2018/10)].

Open Access This article is distributed under the terms of the Creative Commons Attribution 4.0 International License (http://creativeco mmons.org/licenses/by/4.0/), which permits unrestricted use, distribution, and reproduction in any medium, provided you give appropriate credit to the original author(s) and the source, provide a link to the Creative Commons license, and indicate if changes were made.

\section{References}

1. Dityatev A, Rusakov DA (2011) Molecular signals of plasticity at the tetrapartite synapse. Curr Opin Neurobiol 21(2):353-359. https://doi.org/10.1016/j.conb.2010.12.006

2. Ferrer-Ferrer M, Dityatev A (2018) Shaping synapses by the neural extracellular matrix. Front Neuroanat 12:40. https://doi. org/10.3389/fnana.2018.00040

3. Rivera S, Khrestchatisky M, Kaczmarek L, Rosenberg GA, Jaworski DM (2010) Metzincin proteases and their inhibitors: foes or friends in nervous system physiology? J Neurosci 30(46):15337-15357. https://doi.org/10.1523/JNEUR OSCI.3467-10.2010

4. Vafadari B, Salamian A, Kaczmarek L (2016) MMP-9 in translation: from molecule to brain physiology, pathology, and therapy. J Neurochem 139(Suppl 2):91-114. https://doi. org/10.1111/jnc. 13415

5. Sternlicht MD, Werb Z (2001) How matrix metalloproteinases regulate cell behavior. Annu Rev Cell Dev Biol 17:463-516. https://doi.org/10.1146/annurev.cellbio.17.1.463

6. Gu Z, Kaul M, Yan B, Kridel SJ, Cui J, Strongin A, Smith JW, Liddington RC, Lipton SA (2002) S-nitrosylation of matrix metalloproteinases: signaling pathway to neuronal cell death. Science 297(5584):1186-1190. https://doi.org/10.1126/scien ce. 1073634

7. Gossas T, Danielson UH (2006) Characterization of $\mathrm{Ca}^{2+}$ interactions with matrix metallopeptidase-12: implications for matrix metallopeptidase regulation. Biochem J 398(3):393398. https://doi.org/10.1042/BJ20051933

8. Iyer RP, Patterson NL, Fields GB, Lindsey ML (2012) The history of matrix metalloproteinases: milestones, myths, and misperceptions. Am J Physiol Heart Circ Physiol 303(8):H919H930. https://doi.org/10.1152/ajpheart.00577.2012

9. Kaczmarek L, Lapinska-Dzwonek J, Szymczak S (2002) Matrix metalloproteinases in the adult brain physiology: a link between c-Fos, AP-1 and remodeling of neuronal connections? EMBO J 21(24):6643-6648

10. Kuzniewska B, Rejmak E, Malik AR, Jaworski J, Kaczmarek L, Kalita K (2013) Brain-derived neurotrophic factor induces matrix metalloproteinase 9 expression in neurons via the serum response factor/c-Fos pathway. Mol Cell Biol 33(11):2149 2162. https://doi.org/10.1128/MCB.00008-13

11. Dziembowska M, Milek J, Janusz A, Rejmak E, Romanowska E, Gorkiewicz T, Tiron A, Bramham CR, Kaczmarek L (2012) Activity-dependent local translation of matrix metalloproteinase-9. J Neurosci 32(42):14538-14547. https://doi. org/10.1523/JNEUROSCI.6028-11.2012

12. Jasińska M, Miłek J, Cymerman IA, Łęski S, Kaczmarek L, Dziembowska M (2016) miR-132 regulates dendritic spine structure by direct targeting of matrix metalloproteinase 9 mRNA. Mol Neurobiol 53(7):4701-4712. https://doi. org/10.1007/s12035-015-9383-z

13. Zybura-Broda K, Wolder-Gontarek M, Ambrozek-Latecka M, Choros A, Bogusz A, Wilemska-Dziaduszycka J, Rylski M (2018) HuR (Elavl1) and HuB (Elavl2) stabilize matrix metalloproteinase-9 mRNA during seizure-induced Mmp-9 expression in neurons. Front Neurosci 12:224. https://doi. org/10.3389/fnins.2018.00224

14. Sbai O, Ferhat L, Bernard A, Gueye Y, Ould-Yahoui A, Thiolloy S, Charrat E, Charton G, Tremblay E, Risso JJ, Chauvin JP, Arsanto JP, Rivera S, Khrestchatisky M (2008) Vesicular trafficking and secretion of matrix metalloproteinases-2, -9 and tissue inhibitor of metalloproteinases- 1 in neuronal cells. Mol Cell Neurosci 39(4):549-568. https://doi.org/10.1016/j. men.2008.08.004 
15. Sbai O, Ould-Yahoui A, Ferhat L, Gueye Y, Bernard A, Charrat E, Mehanna A, Risso JJ, Chauvin JP, Fenouillet E, Rivera S, Khrestchatisky M (2010) Differential vesicular distribution and trafficking of MMP-2, MMP-9, and their inhibitors in astrocytes. Glia 58(3):344-366. https://doi.org/10.1002/glia.20927

16. Schnaeker EM, Ossig R, Ludwig T, Dreier R, Oberleithner H, Wilhelmi M, Schneider SW (2004) Microtubule-dependent matrix metalloproteinase-2/matrix metalloproteinase- 9 exocytosis: prerequisite in human melanoma cell invasion. Cancer Res 64(24):8924-8931. https://doi.org/10.1158/0008-5472. CAN-04-0324

17. Bourguignon LY, Gunja-Smith Z, Iida N, Zhu HB, Young LJ, Muller WJ, Cardiff RD (1998) CD44v(3,8-10) is involved in cytoskeleton-mediated tumor cell migration and matrix metalloproteinase (MMP-9) association in metastatic breast cancer cells. J Cell Physiol 176(1):206-215. https://doi.org/10.1002/ (SICI) 1097-4652(199807)176:1\%3c206:AID-JCP22 \%3e3.0.CO;2-3

18. Dzwonek J, Wilczynski GM (2015) CD44: molecular interactions, signaling and functions in the nervous system. Front Cell Neurosci 9:175. https://doi.org/10.3389/fncel.2015.00175

19. Wang XQ, Sun P, Paller AS (2003) Ganglioside GM3 inhibits matrix metalloproteinase-9 activation and disrupts its association with integrin. J Biol Chem 278(28):25591-25599. https://doi. org/10.1074/jbc.M302211200

20. Cuzner ML, Opdenakker G (1999) Plasminogen activators and matrix metalloproteases, mediators of extracellular proteolysis in inflammatory demyelination of the central nervous system. $\mathbf{J}$ Neuroimmunol 94(1-2):1-14

21. Pei D, Weiss SJ (1995) Furin-dependent intracellular activation of the human stromelysin-3 zymogen. Nature 375(6528):244247. https://doi.org/10.1038/375244a0

22. Olson MW, Gervasi DC, Mobashery S, Fridman R (1997) Kinetic analysis of the binding of human matrix metalloproteinase- 2 and -9 to tissue inhibitor of metalloproteinase (TIMP)-1 and TIMP-2. J Biol Chem 272(47):29975-29983

23. Gomis-Ruth FX, Maskos K, Betz M, Bergner A, Huber R, Suzuki K, Yoshida N, Nagase H, Brew K, Bourenkov GP, Bartunik H, Bode W (1997) Mechanism of inhibition of the human matrix metalloproteinase stromelysin-1 by TIMP-1. Nature 389(6646):77-81. https://doi.org/10.1038/37995

24. Bjorklund M, Heikkila P, Koivunen E (2004) Peptide inhibition of catalytic and noncatalytic activities of matrix metalloproteinase-9 blocks tumor cell migration and invasion. J Biol Chem 279(28):29589-29597. https://doi.org/10.1074/jbc.M401601200

25. Bruno MA, Cuello AC (2006) Activity-dependent release of precursor nerve growth factor, conversion to mature nerve growth factor, and its degradation by a protease cascade. Proc Natl Acad Sci USA 103(17):6735-6740. https://doi.org/10.1073/ pnas.0510645103

26. Roderfeld M, Graf J, Giese B, Salguero-Palacios R, Tschuschner A, Muller-Newen G, Roeb E (2007) Latent MMP-9 is bound to TIMP-1 before secretion. Biol Chem 388(11):1227-1234. https ://doi.org/10.1515/BC.2007.123

27. Ogata Y, Itoh Y, Nagase H (1995) Steps involved in activation of the pro-matrix metalloproteinase 9 (progelatinase B)-tissue inhibitor of metalloproteinases- 1 complex by 4 -aminophenylmercuric acetate and proteinases. J Biol Chem 270(31):18506-18511

28. Mantuano E, Inoue G, Li X, Takahashi K, Gaultier A, Gonias SL, Campana WM (2008) The hemopexin domain of matrix metalloproteinase- 9 activates cell signaling and promotes migration of schwann cells by binding to low-density lipoprotein receptorrelated protein. J Neurosci 28(45):11571-11582. https://doi. org/10.1523/JNEUROSCI.3053-08.2008

29. Magnowska M, Gorkiewicz T, Suska A, Wawrzyniak M, Rutkowska-Wlodarczyk I, Kaczmarek L, Wlodarczyk J (2016)
Transient ECM protease activity promotes synaptic plasticity. Sci Rep. https://doi.org/10.1038/srep27757

30. Murphy N, Lynch MA (2012) Activation of the P2X(7) receptor induces migration of glial cells by inducing cathepsin B degradation of tissue inhibitor of metalloproteinase 1 . J Neurochem 123(5):761-770. https://doi.org/10.1111/jnc.12031

31. Padamsey Z, McGuinness L, Bardo SJ, Reinhart M, Tong R, Hedegaard A, Hart ML, Emptage NJ (2017) Activity-dependent exocytosis of lysosomes regulates the structural plasticity of dendritic spines. Neuron 93(1):132-146. https://doi.org/10.1016/j. neuron.2016.11.013

32. Strongin AY, Collier I, Bannikov G, Marmer BL, Grant GA, Goldberg GI (1995) Mechanism of cell surface activation of 72-kDa type IV collagenase. Isolation of the activated form of the membrane metalloprotease. J Biol Chem 270(10):5331-5338

33. Hoegy SE, Oh HR, Corcoran ML, Stetler-Stevenson WG (2001) Tissue inhibitor of metalloproteinases-2 (TIMP-2) suppresses TKR-growth factor signaling independent of metalloproteinase inhibition. J Biol Chem 276(5):3203-3214. https://doi. org/10.1074/jbc.M008157200

34. Ries C (2014) Cytokine functions of TIMP-1. Cell Mol Life Sci 71(4):659-672. https://doi.org/10.1007/s00018-013-1457-3

35. Thevenard J, Verzeaux L, Devy J, Etique N, Jeanne A, Schneider C, Hachet C, Ferracci G, David M, Martiny L, Charpentier E, Khrestchatisky M, Rivera S, Dedieu S, Emonard H (2014) Lowdensity lipoprotein receptor-related protein-1 mediates endocytic clearance of tissue inhibitor of metalloproteinases-1 and promotes its cytokine-like activities. PLoS One 9(7):e103839. https ://doi.org/10.1371/journal.pone.0103839

36. Verzeaux L, Belloy N, Thevenard-Devy J, Devy J, Ferracci G, Martiny L, Dedieu S, Dauchez M, Emonard H, Etique N, Devarenne-Charpentier E (2017) Intrinsic dynamics study identifies two amino acids of TIMP-1 critical for its LRP-1-mediated endocytosis in neurons. Sci Rep 7(1):5375. https://doi.org/10.1038/ s41598-017-05039-z

37. Pagenstecher A, Stalder AK, Kincaid CL, Shapiro SD, Campbell IL (1998) Differential expression of matrix metalloproteinase and tissue inhibitor of matrix metalloproteinase genes in the mouse central nervous system in normal and inflammatory states. Am J Pathol 152(3):729-741

38. Sharma NR, Wang X, Majerciak V, Ajiro M, Kruhlak M, Meyers C, Zheng ZM (2016) Cell type- and tissue context-dependent nuclear distribution of human Ago2. J Biol Chem 291(5):23022309. https://doi.org/10.1074/jbc.C115.695049

39. Ierusalimsky VN, Balaban PM (2013) Type 1 metalloproteinase is selectively expressed in adult rat brain and can be rapidly upregulated by kainate. Acta Histochem 115(8):816-826. https:// doi.org/10.1016/j.acthis.2013.04.001

40. Lenglet S, Montecucco F, Mach F, Schaller K, Gasche Y, Copin JC (2014) Analysis of the expression of nine secreted matrix metalloproteinases and their endogenous inhibitors in the brain of mice subjected to ischaemic stroke. Thromb Haemost 112(2):363-378. https://doi.org/10.1160/TH14-01-0007

41. Leake A, Morris CM, Whateley J (2000) Brain matrix metalloproteinase 1 levels are elevated in Alzheimer's disease. Neurosci Lett 291(3):201-203

42. Allen M, Ghosh S, Ahern GP, Villapol S, Maguire-Zeiss KA, Conant K (2016) Protease induced plasticity: matrix metalloproteinase-1 promotes neurostructural changes through activation of protease activated receptor 1 . Sci Rep 6:35497. https://doi. org/10.1038/srep35497

43. Vos CM, Sjulson L, Nath A, McArthur JC, Pardo CA, Rothstein J, Conant K (2000) Cytotoxicity by matrix metalloprotease-1 in organotypic spinal cord and dissociated neuronal cultures. Exp Neurol 163(2):324-330. https://doi.org/10.1006/exnr.2000.7388 
44. Valente MM, Allen M, Bortolotto V, Lim ST, Conant K, Grilli M (2015) The MMP-1/PAR-1 axis enhances proliferation and neuronal differentiation of adult hippocampal neural progenitor cells. Neural Plast 2015:646595. https://doi.org/10.1155/2015/646595

45. Austin KM, Covic L, Kuliopulos A (2013) Matrix metalloproteases and PAR1 activation. Blood 121(3):431-439. https://doi. org/10.1182/blood-2012-09-355958

46. Dzwonek J, Rylski M, Kaczmarek L (2004) Matrix metalloproteinases and their endogenous inhibitors in neuronal physiology of the adult brain. FEBS Lett 567(1):129-135. https://doi. org/10.1016/j.febslet.2004.03.070

47. Szklarczyk A, Lapinska J, Rylski M, McKay RD, Kaczmarek L (2002) Matrix metalloproteinase-9 undergoes expression and activation during dendritic remodeling in adult hippocampus. $\mathbf{J}$ Neurosci 22(3):920-930

48. Aujla PK, Huntley GW (2014) Early postnatal expression and localization of matrix metalloproteinases- 2 and -9 during establishment of rat hippocampal synaptic circuitry. J Comp Neurol 522(6):1249-1263. https://doi.org/10.1002/cne.23468

49. Planas AM, Sole S, Justicia C (2001) Expression and activation of matrix metalloproteinase-2 and -9 in rat brain after transient focal cerebral ischemia. Neurobiol Dis 8(5):834-846. https://doi. org/10.1006/nbdi.2001.0435

50. Smith AC, Kupchik YM, Scofield MD, Gipson CD, Wiggins A, Thomas CA, Kalivas PW (2014) Synaptic plasticity mediating cocaine relapse requires matrix metalloproteinases. Nat Neurosci 17(12):1655-1657. https://doi.org/10.1038/nn.3846

51. Vaillant C, Didier-Bazes M, Hutter A, Belin MF, Thomasset N (1999) Spatiotemporal expression patterns of metalloproteinases and their inhibitors in the postnatal developing rat cerebellum. $\mathrm{J}$ Neurosci 19(12):4994-5004

52. Bednarek N, Clement Y, Lelievre V, Olivier P, Loron G, Garnotel R, Gressens P (2009) Ontogeny of MMPs and TIMPs in the murine neocortex. Pediatr Res 65(3):296-300. https://doi. org/10.1203/PDR.0b013e3181973aee

53. Muir EM, Adcock KH, Morgenstern DA, Clayton R, von Stillfried N, Rhodes K, Ellis C, Fawcett JW, Rogers JH (2002) Matrix metalloproteases and their inhibitors are produced by overlapping populations of activated astrocytes. Brain Res Mol Brain Res 100(1-2):103-117

54. Ogier C, Bernard A, Chollet AM, Le Diguardher T, Hanessian S, Charton G, Khrestchatisky M, Rivera S (2006) Matrix metalloproteinase-2 (MMP-2) regulates astrocyte motility in connection with the actin cytoskeleton and integrins. Glia 54(4):272-284. https://doi.org/10.1002/glia.20349

55. Van Hove I, Lemmens K, Van de Velde S, Verslegers M, Moons L (2012) Matrix metalloproteinase-3 in the central nervous system: a look on the bright side. J Neurochem 123(2):203-216. https://doi.org/10.1111/j.1471-4159.2012.07900.x

56. Del Bigio MR, Jacque CM (1995) Localization of proteinase expression in the developing rabbit brain. Brain Res Dev Brain Res 86(1-2):345-347

57. Wiera G, Nowak D, van Hove I, Dziegiel P, Moons L, Mozrzymas JW (2017) Mechanisms of NMDA receptor- and voltage-gated L-type calcium channel-dependent hippocampal LTP critically rely on proteolysis that is mediated by distinct metalloproteinases. J Neurosci 37(5):1240-1256. https://doi. org/10.1523/JNEUROSCI.2170-16.2016

58. Van Hove I, Verslegers M, Buyens T, Delorme N, Lemmens K, Stroobants S, Gantois I, D'Hooge R, Moons L (2012) An aberrant cerebellar development in mice lacking matrix metalloproteinase-3. Mol Neurobiol 45(1):17-29. https://doi.org/10.1007/ s12035-011-8215-z

59. Ulrich R, Gerhauser I, Seeliger F, Baumgartner W, Alldinger S (2005) Matrix metalloproteinases and their inhibitors in the developing mouse brain and spinal cord: a reverse transcription quantitative polymerase chain reaction study. Dev Neurosci 27(6):408-418. https://doi.org/10.1159/000088455

60. Meighan SE, Meighan PC, Choudhury P, Davis CJ, Olson ML, Zornes PA, Wright JW, Harding JW (2006) Effects of extracellular matrix-degrading proteases matrix metalloproteinases 3 and 9 on spatial learning and synaptic plasticity. J Neurochem 96(5):1227-1241. https://doi.org/10.111 1/j.1471-4159.2005.03565.x

61. Wright JW, Meighan SE, Murphy ES, Holtfreter KL, Davis CJ, Olson ML, Benoist CC, Muhunthan K, Harding JW (2006) Habituation of the head-shake response induces changes in brain matrix metalloproteinases-3 (MMP-3) and -9. Behav Brain Res 174(1):78-85. https://doi.org/10.1016/j. bbr.2006.07.006

62. Gorter JA, Van Vliet EA, Rauwerda H, Breit T, Stad R, van Schaik L, Vreugdenhil E, Redeker S, Hendriksen E, Aronica E, Lopes da Silva FH, Wadman WJ (2007) Dynamic changes of proteases and protease inhibitors revealed by microarray analysis in CA3 and entorhinal cortex during epileptogenesis in the rat. Epilepsia 48(Suppl 5):53-64. https://doi.org/10.111 1/j.1528-1167.2007.01290.x

63. Woo MS, Park JS, Choi IY, Kim WK, Kim HS (2008) Inhibition of MMP-3 or -9 suppresses lipopolysaccharide-induced expression of proinflammatory cytokines and iNOS in microglia. J Neurochem 106(2):770-780. https://doi.org/10.111 $1 / \mathrm{j} .1471-4159.2008 .05430 . x$

64. Witek-Zawada B, Koj A (2003) Regulation of expression of stromyelysin-1 by proinflammatory cytokines in mouse brain astrocytes. J Physiol Pharmacol 54(4):489-496

65. Kim YS, Kim SS, Cho JJ, Choi DH, Hwang O, Shin DH, Chun HS, Beal MF, Joh TH (2005) Matrix metalloproteinase-3: a novel signaling proteinase from apoptotic neuronal cells that activates microglia. J Neurosci 25(14):3701-3711. https://doi.org/10.1523/ JNEUROSCI.4346-04.2005

66. Matsuno H, Yudoh K, Watanabe Y, Nakazawa F, Aono H, Kimura T (2001) Stromelysin-1 (MMP-3) in synovial fluid of patients with rheumatoid arthritis has potential to cleave membrane bound Fas ligand. J Rheumatol 28(1):22-28

67. Kim HJ, Fillmore HL, Reeves TM, Phillips LL (2005) Elevation of hippocampal MMP-3 expression and activity during traumainduced synaptogenesis. Exp Neurol 192(1):60-72. https://doi. org/10.1016/j.expneurol.2004.10.014

68. Skuljec J, Gudi V, Ulrich R, Frichert K, Yildiz O, Pul R, Voss EV, Wissel K, Baumgartner W, Stangel M (2011) Matrix metalloproteinases and their tissue inhibitors in cuprizone-induced demyelination and remyelination of brain white and gray matter. J Neuropathol Exp Neurol 70(9):758-769. https://doi. org/10.1097/NEN.0b013e3182294fad

69. Hughes PM, Wells GM, Perry VH, Brown MC, Miller KM (2002) Comparison of matrix metalloproteinase expression during Wallerian degeneration in the central and peripheral nervous systems. Neuroscience 113(2):273-287

70. Roberts DJ, Jenne CN, Leger C, Kramer AH, Gallagher CN, Todd S, Parney IF, Doig CJ, Yong VW, Kubes P, Zygun DA (2013) A prospective evaluation of the temporal matrix metalloproteinase response after severe traumatic brain injury in humans. J Neurotrauma 30(20):1717-1726. https://doi. org/10.1089/neu.2012.2841

71. Rome C, Arsaut J, Taris C, Couillaud F, Loiseau H (2007) MMP-7 (matrilysin) expression in human brain tumors. Mol Carcinog 46(6):446-452. https://doi.org/10.1002/mc.20293

72. Anthony DC, Ferguson B, Matyzak MK, Miller KM, Esiri MM, Perry VH (1997) Differential matrix metalloproteinase expression in cases of multiple sclerosis and stroke. Neuropathol Appl Neurobiol 23(5):406-415 
73. Cossins JA, Clements JM, Ford J, Miller KM, Pigott R, Vos W, Van der Valk P, De Groot CJ (1997) Enhanced expression of MMP-7 and MMP-9 in demyelinating multiple sclerosis lesions. Acta Neuropathol 94(6):590-598

74. Le AP, Friedman WJ (2012) Matrix metalloproteinase-7 regulates cleavage of pro-nerve growth factor and is neuroprotective following kainic acid-induced seizures. J Neurosci 32(2):703712. https://doi.org/10.1523/JNEUROSCI.4128-11.2012

75. Kieseier BC, Kiefer R, Clements JM, Miller K, Wells GM, Schweitzer T, Gearing AJ, Hartung HP (1998) Matrix metalloproteinase- 9 and -7 are regulated in experimental autoimmune encephalomyelitis. Brain 121(Pt 1):159-166

76. Conant K, McArthur JC, Griffin DE, Sjulson L, Wahl LM, Irani DN (1999) Cerebrospinal fluid levels of MMP-2, 7, and 9 are elevated in association with human immunodeficiency virus dementia. Ann Neurol 46(3):391-398

77. Lee R, Kermani P, Teng KK, Hempstead BL (2001) Regulation of cell survival by secreted proneurotrophins. Science 294(5548):1945-1948. https://doi.org/10.1126/science.1065057

78. Szklarczyk A, Oyler G, McKay R, Gerfen C, Conant K (2007) Cleavage of neuronal synaptosomal-associated protein of $25 \mathrm{kDa}$ by exogenous matrix metalloproteinase-7. J Neurochem 102(4):1256-1263. https://doi.org/10.111 1/j.1471-4159.2007.04625.x

79. Szklarczyk A, Ewaleifoh O, Beique JC, Wang Y, Knorr D, Haughey N, Malpica T, Mattson MP, Huganir R, Conant K (2008) MMP-7 cleaves the NR1 NMDA receptor subunit and modifies NMDA receptor function. FASEB J 22(11):3757-3767. https://doi.org/10.1096/fj.07-101402

80. Milward E, Kim KJ, Szklarczyk A, Nguyen T, Melli G, Nayak M, Deshpande D, Fitzsimmons C, Hoke A, Kerr D, Griffin JW, Calabresi PA, Conant K (2008) Cleavage of myelin associated glycoprotein by matrix metalloproteinases. J Neuroimmunol 193(12):140-148. https://doi.org/10.1016/j.jneuroim.2007.11.001

81. Reinhard SM, Razak K, Ethell IM (2015) A delicate balance: role of MMP-9 in brain development and pathophysiology of neurodevelopmental disorders. Front Cell Neurosci 9:280. https ://doi.org/10.3389/fncel.2015.00280

82. Gawlak M, Gorkiewicz T, Gorlewicz A, Konopacki FA, Kaczmarek L, Wilczynski GM (2009) High resolution in situ zymography reveals matrix metalloproteinase activity at glutamatergic synapses. Neuroscience 158(1):167-176. https://doi. org/10.1016/j.neuroscience.2008.05.045

83. Janusz A, Milek J, Perycz M, Pacini L, Bagni C, Kaczmarek L, Dziembowska M (2013) The Fragile X mental retardation protein regulates matrix metalloproteinase $9 \mathrm{mRNA}$ at synapses. $\mathbf{J}$ Neurosci 33(46):18234-18241. https://doi.org/10.1523/JNEUR OSCI.2207-13.2013

84. Szepesi Z, Hosy E, Ruszczycki B, Bijata M, Pyskaty M, Bikbaev A, Heine M, Choquet D, Kaczmarek L, Wlodarczyk J (2014) Synaptically released matrix metalloproteinase activity in control of structural plasticity and the cell surface distribution of GluA1-AMPA receptors. PLoS One 9(5):e98274. https://doi. org/10.1371/journal.pone.0098274

85. Langenfurth A, Rinnenthal JL, Vinnakota K, Prinz V, Carlo AS, Stadelmann C, Siffrin V, Peaschke S, Endres M, Heppner F, Glass R, Wolf SA, Kettenmann H (2014) Membrane-type 1 metalloproteinase is upregulated in microglia/brain macrophages in neurodegenerative and neuroinflammatory diseases. J Neurosci Res 92(3):275-286. https://doi.org/10.1002/jnr.23288

86. Py NA, Bonnet AE, Bernard A, Marchalant Y, Charrat E, Checler F, Khrestchatisky M, Baranger K, Rivera S (2014) Differential spatio-temporal regulation of MMPs in the $5 \mathrm{xFAD}$ mouse model of Alzheimer's disease: evidence for a pro-amyloidogenic role of MT1-MMP. Front Aging Neurosci 6:247. https://doi. org/10.3389/fnagi.2014.00247
87. Cazzin C, Mion S, Caldara F, Rimland JM, Domenici E (2011) Microarray analysis of cultured rat hippocampal neurons treated with brain derived neurotrophic factor. Mol Biol Rep 38(2):983990. https://doi.org/10.1007/s11033-010-0193-0

88. De Groef L, Andries L, Lemmens K, Van Hove I, Moons L (2015) Matrix metalloproteinases in the mouse retina: a comparative study of expression patterns and MMP antibodies. BMC Ophthalmol 15:187. https://doi.org/10.1186/s12886-015-0176-y

89. Irwin LN, Byers DM (2012) Novel odors affect gene expression for cytokines and proteinases in the rat amygdala and hippocampus. Brain Res 1489:1-7. https://doi.org/10.1016/j.brain res.2012.10.034

90. Jaworski DM (2000) Developmental regulation of membrane type-5 matrix metalloproteinase (MT5-MMP) expression in the rat nervous system. Brain Res 860(1-2):174-177

91. Sekine-Aizawa Y, Hama E, Watanabe K, Tsubuki S, KanaiAzuma M, Kanai Y, Arai H, Aizawa H, Iwata N, Saido TC (2001) Matrix metalloproteinase (MMP) system in brain: identification and characterization of brain-specific MMP highly expressed in cerebellum. Eur J Neurosci 13(5):935-948

92. Hayashita-Kinoh H, Kinoh H, Okada A, Komori K, Itoh Y, Chiba T, Kajita M, Yana I, Seiki M (2001) Membrane-type 5 matrix metalloproteinase is expressed in differentiated neurons and regulates axonal growth. Cell Growth Differ 12(11):573-580

93. Sala C, Segal M (2014) Dendritic spines: the locus of structural and functional plasticity. Physiol Rev 94(1):141-188. https://doi. org/10.1152/physrev.00012.2013

94. Lee H, Lee EJ, Song YS, Kim E (2014) Long-term depressioninducing stimuli promote cleavage of the synaptic adhesion molecule NGL-3 through NMDA receptors, matrix metalloproteinases and presenilin/gamma-secretase. Philos Trans R Soc Lond B Biol Sci 369(1633):20130158. https://doi.org/10.1098/ rstb.2013.0158

95. Meighan PC, Meighan SE, Davis CJ, Wright JW, Harding JW (2007) Effects of matrix metalloproteinase inhibition on short- and long-term plasticity of schaffer collateral/CA1 synapses. J Neurochem 102(6):2085-2096. https://doi.org/10.111 1/j.1471-4159.2007.04682.x

96. Wojtowicz T, Mozrzymas JW (2010) Late phase of long-term potentiation in the mossy fiber-CA3 hippocampal pathway is critically dependent on metalloproteinases activity. Hippocampus 20(8):917-921. https://doi.org/10.1002/hipo.20787

97. Kaliszewska A, Bijata M, Kaczmarek L, Kossut M (2012) Experience-dependent plasticity of the barrel cortex in mice observed with 2-DG brain mapping and c-Fos: effects of MMP-9 KO. Cereb Cortex 22(9):2160-2170. https://doi.org/10.1093/cercor/ bhr303

98. Pielecka-Fortuna J, Kalogeraki E, Fortuna MG, Lowel S (2015) Optimal level activity of matrix metalloproteinases is critical for adult visual plasticity in the healthy and stroke-affected brain. Elife 5:e11290. https://doi.org/10.7554/eLife.11290

99. Spolidoro M, Putignano E, Munafo C, Maffei L, Pizzorusso $T$ (2012) Inhibition of matrix metalloproteinases prevents the potentiation of nondeprived-eye responses after monocular deprivation in juvenile rats. Cereb Cortex 22(3):725-734. https:// doi.org/10.1093/cercor/bhr158

100. Dityatev A, Schachner M, Sonderegger P (2010) The dual role of the extracellular matrix in synaptic plasticity and homeostasis. Nat Rev Neurosci 11(11):735-746. https://doi.org/10.1038/nrn28 98

101. Huntley GW (2012) Synaptic circuit remodelling by matrix metalloproteinases in health and disease. Nat Rev Neurosci 13(11):743-757. https://doi.org/10.1038/nrn3320

102. Michaluk P, Kaczmarek L (2007) Matrix metalloproteinase-9 in glutamate-dependent adult brain function and dysfunction. 
Cell Death Differ 14(7):1255-1258. https://doi.org/10.1038/ sj.cdd.4402141

103. Tsilibary E, Tzinia A, Radenovic L, Stamenkovic V, Lebitko T, Mucha M, Pawlak R, Frischknecht R, Kaczmarek L (2014) Neural ECM proteases in learning and synaptic plasticity. Prog Brain Res 214:135-157. https://doi.org/10.1016/B978-0-44463486-3.00006-2

104. Michaluk P, Kolodziej L, Mioduszewska B, Wilczynski GM, Dzwonek J, Jaworski J, Gorecki DC, Ottersen OP, Kaczmarek L (2007) Beta-dystroglycan as a target for MMP-9, in response to enhanced neuronal activity. J Biol Chem 282(22):16036-16041. https://doi.org/10.1074/jbc.M700641200

105. Peixoto RT, Kunz PA, Kwon H, Mabb AM, Sabatini BL, Philpot BD, Ehlers MD (2012) Transsynaptic signaling by activitydependent cleavage of neuroligin-1. Neuron 76(2):396-409. https://doi.org/10.1016/j.neuron.2012.07.006

106. van der Kooij MA, Fantin M, Rejmak E, Grosse J, Zanoletti O, Fournier C, Ganguly K, Kalita K, Kaczmarek L, Sandi C (2014) Role for MMP-9 in stress-induced downregulation of nectin-3 in hippocampal CA1 and associated behavioural alterations. Nat Commun 5:4995. https://doi.org/10.1038/ncomm s5995

107. Conant K, Lonskaya I, Szklarczyk A, Krall C, Steiner J, MaguireZeiss K, Lim ST (2011) Methamphetamine-associated cleavage of the synaptic adhesion molecule intercellular adhesion molecule-5. J Neurochem 118(4):521-532. https://doi.org/10.111 1/j.1471-4159.2010.07153.x

108. Kelly EA, Tremblay ME, Gahmberg CG, Tian L, Majewska AK (2014) Subcellular localization of intercellular adhesion molecule-5 (telencephalin) in the visual cortex is not developmentally regulated in the absence of matrix metalloproteinase-9. J Comp Neurol 522(3):676-688. https://doi.org/10.1002/cne.23440

109. Bajor M, Michaluk P, Gulyassy P, Kekesi AK, Juhasz G, Kaczmarek L (2012) Synaptic cell adhesion molecule-2 and collapsin response mediator protein- 2 are novel members of the matrix metalloproteinase-9 degradome. J Neurochem 122(4):775-788. https://doi.org/10.1111/j.1471-4159.2012.07829.x

110. Gorkiewicz T, Szczuraszek K, Wyrembek P, Michaluk P, Kaczmarek L, Mozrzymas JW (2010) Matrix metalloproteinase-9 reversibly affects the time course of NMDA-induced currents in cultured rat hippocampal neurons. Hippocampus 20(10):11051108. https://doi.org/10.1002/hipo.20736

111. Michaluk P, Mikasova L, Groc L, Frischknecht R, Choquet D, Kaczmarek L (2009) Matrix metalloproteinase-9 controls NMDA receptor surface diffusion through integrin beta1 signaling. $\mathrm{J}$ Neurosci 29(18):6007-6012. https://doi.org/10.1523/JNEUR OSCI.5346-08.2009

112. Lonskaya I, Partridge J, Lalchandani RR, Chung A, Lee T, Vicini S, Hoe HS, Lim ST, Conant K (2013) Soluble ICAM-5, a product of activity dependent proteolysis, increases mEPSC frequency and dendritic expression of GluA1. PLoS One 8(7):e69136. https ://doi.org/10.1371/journal.pone.0069136

113. Niedringhaus M, Chen X, Conant K, Dzakpasu R (2013) Synaptic potentiation facilitates memory-like attractor dynamics in cultured in vitro hippocampal networks. PLoS One 8(3):e57144. https://doi.org/10.1371/journal.pone.0057144

114. Niedringhaus M, Chen X, Dzakpasu R, Conant K (2012) MMPs and soluble ICAM-5 increase neuronal excitability within in vitro networks of hippocampal neurons. PLoS One 7(8):e42631. https ://doi.org/10.1371/journal.pone.0042631

115. Szepesi Z, Bijata M, Ruszczycki B, Kaczmarek L, Wlodarczyk J (2013) Matrix metalloproteinases regulate the formation of dendritic spine head protrusions during chemically induced long-term potentiation. PLoS One 8(5):e63314. https://doi. org/10.1371/journal.pone.0063314
116. Bozdagi O, Nagy V, Kwei KT, Huntley GW (2007) In vivo roles for matrix metalloproteinase-9 in mature hippocampal synaptic physiology and plasticity. J Neurophysiol 98(1):334-344. https ://doi.org/10.1152/jn.00202.2007

117. Nagy V, Bozdagi O, Matynia A, Balcerzyk M, Okulski P, Dzwonek J, Costa RM, Silva AJ, Kaczmarek L, Huntley GW (2006) Matrix metalloproteinase-9 is required for hippocampal late-phase long-term potentiation and memory. J Neurosci 26(7):1923-1934. https://doi.org/10.1523/JNEUR OSCI.4359-05.2006

118. Wang XB, Bozdagi O, Nikitczuk JS, Zhai ZW, Zhou Q, Huntley GW (2008) Extracellular proteolysis by matrix metalloproteinase-9 drives dendritic spine enlargement and long-term potentiation coordinately. Proc Natl Acad Sci USA 105(49):19520 19525. https://doi.org/10.1073/pnas.0807248105

119. Wiera G, Wozniak G, Bajor M, Kaczmarek L, Mozrzymas JW (2013) Maintenance of long-term potentiation in hippocampal mossy fiber-CA3 pathway requires fine-tuned MMP-9 proteolytic activity. Hippocampus 23(6):529-543. https://doi.org/10.1002/ hipo. 22112

120. Okulski P, Jay TM, Jaworski J, Duniec K, Dzwonek J, Konopacki FA, Wilczynski GM, Sanchez-Capelo A, Mallet J, Kaczmarek L (2007) TIMP-1 abolishes MMP-9-dependent long-lasting long-term potentiation in the prefrontal cortex. Biol Psychiatry 62(4):359-362. https://doi.org/10.1016/j.biopsych.2006.09.012

121. Gorkiewicz T, Balcerzyk M, Kaczmarek L, Knapska E (2015) Matrix metalloproteinase 9 (MMP-9) is indispensable for long term potentiation in the central and basal but not in the lateral nucleus of the amygdala. Front Cell Neurosci 9:73. https://doi. org/10.3389/fncel.2015.00073

122. Bilousova TV, Rusakov DA, Ethell DW, Ethell IM (2006) Matrix metalloproteinase-7 disrupts dendritic spines in hippocampal neurons through NMDA receptor activation. J Neurochem 97(1):44-56. https://doi.org/10.1111/j.1471-4159.2006.03701.x

123. Michaluk P, Wawrzyniak M, Alot P, Szczot M, Wyrembek P, Mercik K, Medvedev N, Wilczek E, De Roo M, Zuschratter W, Muller D, Wilczynski GM, Mozrzymas JW, Stewart MG, Kaczmarek L, Wlodarczyk J (2011) Influence of matrix metalloproteinase MMP-9 on dendritic spine morphology. J Cell Sci 124(Pt 19):3369-3380. https://doi.org/10.1242/jcs.090852

124. Tian L, Stefanidakis M, Ning L, Van Lint P, Nyman-Huttunen $\mathrm{H}$, Libert C, Itohara S, Mishina M, Rauvala H, Gahmberg CG (2007) Activation of NMDA receptors promotes dendritic spine development through MMP-mediated ICAM-5 cleavage. J Cell Biol 178(4):687-700. https://doi.org/10.1083/jcb.200612097

125. Rivera S, Tremblay E, Timsit S, Canals O, Ben-Ari Y, Khrestchatisky M (1997) Tissue inhibitor of metalloproteinases-1 (TIMP-1) is differentially induced in neurons and astrocytes after seizures: evidence for developmental, immediate early gene, and lesion response. J Neurosci 17(11):4223-4235

126. Knapska E, Lioudyno V, Kiryk A, Mikosz M, Gorkiewicz T, Michaluk P, Gawlak M, Chaturvedi M, Mochol G, Balcerzyk M, Wojcik DK, Wilczynski GM, Kaczmarek L (2013) Reward learning requires activity of matrix metalloproteinase- 9 in the central amygdala. J Neurosci 33(36):14591-14600. https://doi. org/10.1523/JNEUROSCI.5239-12.2013

127. Brown TE, Wilson AR, Cocking DL, Sorg BA (2009) Inhibition of matrix metalloproteinase activity disrupts reconsolidation but not consolidation of a fear memory. Neurobiol Learn Mem 91(1):66-72. https://doi.org/10.1016/j.nlm.2008.09.003

128. Wright JW, Brown TE, Harding JW (2007) Inhibition of hippocampal matrix metalloproteinase-3 and -9 disrupts spatial memory. Neural Plast 2007:73813. https://doi. org/10.1155/2007/73813 
129. Bach DR, Tzovara A, Vunder J (2017) Blocking human fear memory with the matrix metalloproteinase inhibitor doxycycline. Mol Psychiatry. https://doi.org/10.1038/mp.2017.65

130. Bobinska K, Szemraj J, Galecki P, Talarowska M (2016) The role of MMP genes in recurrent depressive disorders and cognitive functions. Acta Neuropsychiatr 28(4):221-231. https://doi. org/10.1017/neu.2015.72

131. Matsumoto J, Hirano Y, Hashimoto K, Ishima T, Kanahara N, Niitsu T, Shiina A, Hashimoto T, Sato Y, Yokote K, Murano S, Kimura H, Hosoda Y, Shimizu E, Iyo M, Nakazato M (2017) Altered serum level of matrix metalloproteinase-9 and its association with decision-making in eating disorders. Psychiatry Clin Neurosci 71(2):124-134. https://doi.org/10.1111/pcn.12490

132. Rybakowski JK, Skibinska M, Leszczynska-Rodziewicz A, Kaczmarek L, Hauser J (2009) Matrix metalloproteinase-9 gene modulates prefrontal cognition in bipolar men. Psychiatr Genet 19(2):108-109. https://doi.org/10.1097/YPG.0b013 e32832080be

133. Gregory MD, Kippenhan JS, Callicott JH, Rubinstein DY, Mattay VS, Coppola R, Berman KF (2019) Sequence variation associated with SLC12A5 gene expression is linked to brain structure and function in healthy adults. Cereb Cortex. https:// doi.org/10.1093/cercor/bhy344

134. Olson ML, Meighan PC, Brown TE, Asay AL, Benoist CC, Harding JW, Wright JW (2008) Hippocampal MMP-3 elevation is associated with passive avoidance conditioning. Regul Pept 146(1-3):19-25. https://doi.org/10.1016/j.regpep.2007.07.004

135. Wright JW, Meighan PC, Brown TE, Wiediger RV, Sorg BA, Harding JW (2009) Habituation-induced neural plasticity in the hippocampus and prefrontal cortex mediated by MMP3. Behav Brain Res 203(1):27-34. https://doi.org/10.1016/j. bbr.2009.04.014

136. Wiediger RV, Wright JW (2009) Influence of dorsal hippocampal lesions and MMP inhibitors on spontaneous recovery following a habituation/classical conditioning head-shake task. Neurobiol Learn Mem 92(4):504-511. https://doi. org/10.1016/j.nlm.2009.06.009

137. Brzdak P, Wojcicka O, Zareba-Koziol M, Minge D, Henneberger C, Wlodarczyk J, Mozrzymas JW, Wojtowicz T (2017) Synaptic potentiation at basal and apical dendrites of hippocampal pyramidal neurons involves activation of a distinct set of extracellular and intracellular molecular cues. Cereb Cortex. https://doi.org/10.1093/cercor/bhx324

138. Wojtowicz T, Mozrzymas JW (2014) Matrix metalloprotease activity shapes the magnitude of EPSPs and spike plasticity within the hippocampal CA3 network. Hippocampus 24(2):135-153. https://doi.org/10.1002/hipo.22205

139. Pauly T, Ratliff M, Pietrowski E, Neugebauer R, Schlicksupp A, Kirsch J, Kuhse J (2008) Activity-dependent shedding of the NMDA receptor glycine binding site by matrix metalloproteinase 3: a PUTATIVE mechanism of postsynaptic plasticity. PLoS One 3(7):e2681. https://doi.org/10.1371/journ al.pone. 0002681

140. Aerts J, Nys J, Moons L, Hu TT, Arckens L (2015) Altered neuronal architecture and plasticity in the visual cortex of adult MMP-3-deficient mice. Brain Struct Funct 220(5):2675-2689. https://doi.org/10.1007/s00429-014-0819-4

141. Monea S, Jordan BA, Srivastava S, DeSouza S, Ziff EB (2006) Membrane localization of membrane type 5 matrix metalloproteinase by AMPA receptor binding protein and cleavage of cadherins. J Neurosci 26(8):2300-2312. https://doi.org/10.1523/ JNEUROSCI.3521-05.2006

142. Willem M, Tahirovic S, Busche MA, Ovsepian SV, Chafai M, Kootar S, Hornburg D, Evans LD, Moore S, Daria A, Hampel H, Muller V, Giudici C, Nuscher B, Wenninger-Weinzierl A, Kremmer E, Heneka MT, Thal DR, Giedraitis V, Lannfelt L,
Muller U, Livesey FJ, Meissner F, Herms J, Konnerth A, Marie $\mathrm{H}$, Haass C (2015) eta-Secretase processing of APP inhibits neuronal activity in the hippocampus. Nature 526(7573):443447. https://doi.org/10.1038/nature14864

143. Warren KM, Reeves TM, Phillips LL (2012) MT5-MMP, ADAM-10, and N-cadherin act in concert to facilitate synapse reorganization after traumatic brain injury. J Neurotrauma 29(10):1922-1940. https://doi.org/10.1089/neu.2012.2383

144. Berg AT, Cross JH (2010) Towards a modern classification of the epilepsies? Lancet Neurol 9(5):459-461. https://doi. org/10.1016/S1474-4422(10)70024-7

145. Lukasiuk K, Wilczynski GM, Kaczmarek L (2011) Extracellular proteases in epilepsy. Epilepsy Res 96(3):191-206. https ://doi.org/10.1016/j.eplepsyres.2011.08.002

146. Hauser WA, Beghi E (2008) First seizure definitions and worldwide incidence and mortality. Epilepsia 49(Suppl 1):8-12. https ://doi.org/10.1111/j.1528-1167.2008.01443.x

147. Engel J Jr (1996) Epilepsy: structural or functional? AJNR Am J Neuroradiol 17(2):243-244

148. Mikkonen M, Soininen H, Kalvianen R, Tapiola T, Ylinen A, Vapalahti M, Paljarvi L, Pitkanen A (1998) Remodeling of neuronal circuitries in human temporal lobe epilepsy: increased expression of highly polysialylated neural cell adhesion molecule in the hippocampus and the entorhinal cortex. Ann Neurol 44(6):923-934. https://doi.org/10.1002/ana.410440611

149. Sutula T, Cascino G, Cavazos J, Parada I, Ramirez L (1989) Mossy fiber synaptic reorganization in the epileptic human temporal lobe. Ann Neurol 26(3):321-330. https://doi.org/10.1002/ ana.410260303

150. Pitkanen A, Lukasiuk K (2011) Mechanisms of epileptogenesis and potential treatment targets. Lancet Neurol 10(2):173-186. https://doi.org/10.1016/S1474-4422(10)70310-0

151. Bronisz E, Kurkowska-Jastrzebska I (2016) Matrix metalloproteinase 9 in epilepsy: the role of neuroinflammation in seizure development. Mediat Inflamm 2016:7369020. https://doi. org/10.1155/2016/7369020

152. Zhang JW, Deb S, Gottschall PE (1998) Regional and differential expression of gelatinases in rat brain after systemic kainic acid or bicuculline administration. Eur J Neurosci 10(11):3358-3368

153. Zhang JW, Deb S, Gottschall PE (2000) Regional and age-related expression of gelatinases in the brains of young and old rats after treatment with kainic acid. Neurosci Lett 295(1-2):9-12

154. Wilczynski GM, Konopacki FA, Wilczek E, Lasiecka Z, Gorlewicz A, Michaluk P, Wawrzyniak M, Malinowska M, Okulski P, Kolodziej LR, Konopka W, Duniec K, Mioduszewska B, Nikolaev E, Walczak A, Owczarek D, Gorecki DC, Zuschratter W, Ottersen OP, Kaczmarek L (2008) Important role of matrix metalloproteinase 9 in epileptogenesis. J Cell Biol 180(5):10211035. https://doi.org/10.1083/jcb.200708213

155. Mizoguchi H, Nakade J, Tachibana M, Ibi D, Someya E, Koike H, Kamei H, Nabeshima T, Itohara S, Takuma K, Sawada M, Sato J, Yamada K (2011) Matrix metalloproteinase-9 contributes to kindled seizure development in pentylenetetrazole-treated mice by converting pro-BDNF to mature BDNF in the hippocampus. J Neurosci 31(36):12963-12971. https://doi.org/10.1523/ JNEUROSCI.3118-11.2011

156. Kim GW, Kim HJ, Cho KJ, Kim HW, Cho YJ, Lee BI (2009) The role of MMP-9 in integrin-mediated hippocampal cell death after pilocarpine-induced status epilepticus. Neurobiol Dis 36(1):169180. https://doi.org/10.1016/j.nbd.2009.07.008

157. Takacs E, Nyilas R, Szepesi Z, Baracskay P, Karlsen B, Rosvold T, Bjorkum AA, Czurko A, Kovacs Z, Kekesi AK, Juhasz G (2010) Matrix metalloproteinase- 9 activity increased by two different types of epileptic seizures that do not induce neuronal death: a possible role in homeostatic synaptic plasticity. 
Neurochem Int 56(6-7):799-809. https://doi.org/10.1016/j.neuin t.2010.03.003

158. Frey LC (2003) Epidemiology of posttraumatic epilepsy: a critical review. Epilepsia 44(s10):11-17

159. Falo MC, Fillmore HL, Reeves TM, Phillips LL (2006) Matrix metalloproteinase-3 expression profile differentiates adaptive and maladaptive synaptic plasticity induced by traumatic brain injury. J Neurosci Res 84(4):768-781. https://doi.org/10.1002/jnr.20986

160. Falo MC, Reeves TM, Phillips LL (2008) Agrin expression during synaptogenesis induced by traumatic brain injury. J Neurotrauma 25(7):769-783. https://doi.org/10.1089/neu.2008.0511

161. Jia F, Pan YH, Mao Q, Liang YM, Jiang JY (2010) Matrix metalloproteinase-9 expression and protein levels after fluid percussion injury in rats: the effect of injury severity and brain temperature. J Neurotrauma 27(6):1059-1068. https://doi.org/10.1089/ neu.2009.1067

162. Truettner JS, Alonso OF, Dietrich WD (2005) Influence of therapeutic hypothermia on matrix metalloproteinase activity after traumatic brain injury in rats. J Cereb Blood Flow Metab 25(11):1505-1516. https://doi.org/10.1038/sj.jcbfm.9600150

163. Hayashi T, Kaneko Y, Yu S, Bae E, Stahl CE, Kawase T, van Loveren H, Sanberg PR, Borlongan CV (2009) Quantitative analyses of matrix metalloproteinase activity after traumatic brain injury in adult rats. Brain Res 1280:172-177. https://doi. org/10.1016/j.brainres.2009.05.040

164. Wang X, Jung J, Asahi M, Chwang W, Russo L, Moskowitz MA, Dixon CE, Fini ME, Lo EH (2000) Effects of matrix metalloproteinase-9 gene knock-out on morphological and motor outcomes after traumatic brain injury. J Neurosci 20(18):7037-7042

165. von Gertten C, Holmin S, Mathiesen T, Nordqvist AC (2003) Increases in matrix metalloproteinase- 9 and tissue inhibitor of matrix metalloproteinase-1 mRNA after cerebral contusion and depolarisation. J Neurosci Res 73(6):803-810. https://doi. org/10.1002/jnr.10729

166. Mizoguchi H, Yamada K (2013) Roles of matrix metalloproteinases and their targets in epileptogenesis and seizures. Clin Psychopharmacol Neurosci 11(2):45-52. https://doi.org/10.9758/ cpn.2013.11.2.45

167. Pijet B, Stefaniuk M, Kostrzewska-Ksiezyk A, Tsilibary PE, Tzinia A, Kaczmarek L (2018) Elevation of MMP-9 levels promotes epileptogenesis after traumatic brain injury. Mol Neurobiol 1:1. https://doi.org/10.1007/s12035-018-1061-5

168. Hoehna Y, Uckermann O, Luksch H, Stefovska V, Marzahn J, Theil M, Gorkiewicz T, Gawlak M, Wilczynski GM, Kaczmarek L, Ikonomidou C (2012) Matrix metalloproteinase 9 regulates cell death following pilocarpine-induced seizures in the developing brain. Neurobiol Dis 48(3):339-347. https://doi. org/10.1016/j.nbd.2012.06.023

169. Jourquin J, Tremblay E, Decanis N, Charton G, Hanessian S, Chollet AM, Le Diguardher T, Khrestchatisky M, Rivera S (2003) Neuronal activity-dependent increase of net matrix metalloproteinase activity is associated with MMP-9 neurotoxicity after kainate. Eur J Neurosci 18(6):1507-1517

170. Yeghiazaryan M, Rutkowska-Wlodarczyk I, Konopka A, Wilczynski GM, Melikyan A, Korkotian E, Kaczmarek L, Figiel I (2014) DP-b99 modulates matrix metalloproteinase activity and neuronal plasticity. PLoS One 9(6):e99789. https://doi. org/10.1371/journal.pone.0099789

171. Yin P, Yang L, Zhou HY, Sun RP (2011) Matrix metalloproteinase- 9 may be a potential therapeutic target in epilepsy. Med Hypotheses 76(2):184-186. https://doi.org/10.1016/j. mehy.2010.09.013

172. Leppert D, Leib SL, Grygar C, Miller KM, Schaad UB, Hollander GA (2000) Matrix metalloproteinase (MMP)-8 and MMP-9 in cerebrospinal fluid during bacterial meningitis: association with blood-brain barrier damage and neurological sequelae. Clin Infect Dis 31(1):80-84. https://doi.org/10.1086/313922

173. Li YJ, Wang ZH, Zhang B, Zhe X, Wang MJ, Shi ST, Bai J, Lin T, Guo CJ, Zhang SJ, Kong XL, Zuo X, Zhao H (2013) Disruption of the blood-brain barrier after generalized tonic-clonic seizures correlates with cerebrospinal fluid MMP-9 levels. J Neuroinflammation 10:80. https://doi.org/10.1186/1742-2094-10-80

174. Romi F, Helgeland G, Gilhus NE (2012) Serum levels of matrix metalloproteinases: implications in clinical neurology. Eur Neurol 67(2):121-128. https://doi.org/10.1159/000334862

175. Suenaga N, Ichiyama T, Kubota M, Isumi H, Tohyama J, Furukawa S (2008) Roles of matrix metalloproteinase-9 and tissue inhibitors of metalloproteinases 1 in acute encephalopathy following prolonged febrile seizures. J Neurol Sci 266(1-2):126130. https://doi.org/10.1016/j.jns.2007.09.011

176. Ichiyama T, Morishima T, Kajimoto M, Matsushige T, Matsubara T, Furukawa S (2007) Matrix metalloproteinase-9 and tissue inhibitors of metalloproteinases 1 in influenza-associated encephalopathy. Pediatr Infect Dis J 26(6):542-544. https://doi. org/10.1097/INF.0b013e31803994a0

177. Gupta RK, Awasthi R, Garg RK, Kumar N, Gupta PK, Singh AK, Sahoo P, Paliwal VK, Prasad KN, Pandey CM, Rathore RK (2013) T1-weighted dynamic contrast-enhanced MR evaluation of different stages of neurocysticercosis and its relationship with serum MMP-9 expression. AJNR Am J Neuroradiol 34(5):9971003. https://doi.org/10.3174/ajnr.A3346

178. Acar G, Tanriover G, Acar F, Demir R (2015) Increased expression of matrix metalloproteinase- 9 in patients with temporal lobe epilepsy. Turk Neurosurg 25(5):749-756. https://doi. org/10.5137/1019-5149.JTN.10738-14.0

179. Konopka A, Grajkowska W, Ziemianska K, Roszkowski M, Daszkiewicz P, Rysz A, Marchel A, Koperski L, Wilczynski GM, Dzwonek J (2013) Matrix metalloproteinase-9 (MMP-9) in human intractable epilepsy caused by focal cortical dysplasia. Epilepsy Res 104(1-2):45-58. https://doi.org/10.1016/j.eplep syres.2012.09.018

180. Li S, Yu S, Zhang C, Shu H, Liu S, An N, Yang M, Yin Q, Yang $H$ (2012) Increased expression of matrix metalloproteinase 9 in cortical lesions from patients with focal cortical dysplasia type IIb and tuberous sclerosis complex. Brain Res 1453:46-55. https ://doi.org/10.1016/j.brainres.2012.03.009

181. Quirico-Santos T, Nascimento Mello A, Casimiro Gomes A, de Carvalho LP, de Souza JM, Alves-Leon S (2013) Increased metalloprotease activity in the epileptogenic lesion-lobectomy reduces metalloprotease activity and urokinase-type uPAR circulating levels. Brain Res 1538:172-181. https://doi.org/10.1016/j. brainres.2013.09.044

182. Zybura-Broda K, Amborska R, Ambrozek-Latecka M, Wilemska J, Bogusz A, Bucko J, Konopka A, Grajkowska W, Roszkowski M, Marchel A, Rysz A, Koperski L, Wilczynski GM, Kaczmarek L, Rylski M (2016) Epigenetics of epileptogenesis-evoked upregulation of matrix metalloproteinase-9 in hippocampus. PLoS One 11(8):e0159745. https://doi.org/10.1371/journal.pone.0159745

183. Shahar E, Attias U, Savulescu D, Genizin J, Gavish M, Nagler $\mathrm{R}$ (2014) Oxidative stress, metalloproteinase and LDH in children with intractable and non-intractable epilepsy as reflected in salivary analysis. Epilepsy Res 108(1):117-124. https://doi. org/10.1016/j.eplepsyres.2013.10.003

184. Ikonomidou C (2014) Matrix metalloproteinases and epileptogenesis. Mol Cell Pediatr 1(1):6. https://doi.org/10.1186/s4034 8-014-0006-y

185. Wang R, Zeng GQ, Tong RZ, Zhou D, Hong Z (2016) Serum matrix metalloproteinase-2: a potential biomarker for diagnosis of epilepsy. Epilepsy Res 122:114-119. https://doi.org/10.1016/j. eplepsyres.2016.02.009 
186. Lee J, Lim E, Kim Y, Li E, Park S (2010) Ghrelin attenuates kainic acid-induced neuronal cell death in the mouse hippocampus. J Endocrinol 205(3):263-270. https://doi.org/10.1677/ JOE-10-0040

187. Penkowa M, Florit S, Giralt M, Quintana A, Molinero A, Carrasco J, Hidalgo J (2005) Metallothionein reduces central nervous system inflammation, neurodegeneration, and cell death following kainic acid-induced epileptic seizures. J Neurosci Res 79(4):522-534. https://doi.org/10.1002/jnr.20387

188. Grossetete M, Phelps J, Arko L, Yonas H, Rosenberg GA (2009) Elevation of matrix metalloproteinases 3 and 9 in cerebrospinal fluid and blood in patients with severe traumatic brain injury. Neurosurgery 65(4):702-708. https://doi.org/10.1227/01. NEU.0000351768.11363.48

189. Gorter JA, van Vliet EA, Aronica E (2015) Status epilepticus, blood-brain barrier disruption, inflammation, and epileptogenesis. Epilepsy Behav 49:13-16. https://doi.org/10.1016/j.yebeh .2015.04.047

190. World Health Organization (2013) Investing in mental health: Evidence for action. WHO Library Cataloguing-in-Publication Data. http://www.who.int/mental_health/publications/finan cing/investing_in_mh_2013/en/. Accessed 5 June 2019

191. Stein DJ, Phillips KA, Bolton D, Fulford KW, Sadler JZ, Kendler KS (2010) What is a mental/psychiatric disorder? From DSM-IV to DSM-V. Psychol Med 40(11):1759-1765. https:// doi.org/10.1017/S0033291709992261

192. Brus MJ, Solanto MV, Goldberg JF (2014) Adult ADHD vs. bipolar disorder in the DSM-5 era: a challenging differentiation for clinicians. J Psychiatr Pract 20(6):428-437. https://doi. org/10.1097/01.pra.0000456591.20622.9e

193. Zhang B, Henney A, Eriksson P, Hamsten A, Watkins H, Ye S (1999) Genetic variation at the matrix metalloproteinase-9 locus on chromosome 20q12.2-13.1. Hum Genet 105(5):418-423

194. Bobinska K, Szemraj J, Czarny P, Galecki P (2016) Role of MMP-2, MMP-7, MMP-9 and TIMP-2 in the development of recurrent depressive disorder. J Affect Disord 205:119-129. https ://doi.org/10.1016/j.jad.2016.03.068

195. Lundberg AK, Jonsson S, Stenmark J, Kristenson M, Jonasson L (2016) Stress-induced release of matrix metalloproteinase-9 in patients with coronary artery disease: the possible influence of cortisol. Psychoneuroendocrinology 73:117-124. https://doi. org/10.1016/j.psyneuen.2016.07.219

196. Domenici E, Wille DR, Tozzi F, Prokopenko I, Miller S, McKeown A, Brittain C, Rujescu D, Giegling I, Turck CW, Holsboer F, Bullmore ET, Middleton L, Merlo-Pich E, Alexander RC, Muglia P (2010) Plasma protein biomarkers for depression and schizophrenia by multi analyte profiling of case-control collections. PLoS One 5(2):e9166. https://doi.org/10.1371/journ al.pone.0009166

197. Yoshida T, Ishikawa M, Niitsu T, Nakazato M, Watanabe H, Shiraishi T, Shiina A, Hashimoto T, Kanahara N, Hasegawa T, Enohara M, Kimura A, Iyo M, Hashimoto K (2012) Decreased serum levels of mature brain-derived neurotrophic factor (BDNF), but not its precursor proBDNF, in patients with major depressive disorder. PLoS One 7(8):e42676. https://doi.org/10.1371/journ al.pone. 0042676

198. Garvin P, Nilsson L, Carstensen J, Jonasson L, Kristenson M (2009) Plasma levels of matrix metalloproteinase-9 are independently associated with psychosocial factors in a middle-aged normal population. Psychosom Med 71(3):292-300. https://doi. org/10.1097/PSY.0b013e3181960e7f

199. Shibasaki C, Takebayashi M, Itagaki K, Abe H, Kajitani N, Okada-Tsuchioka M, Yamawaki S (2016) Altered serum levels of matrix metalloproteinase-2, -9 in response to electroconvulsive therapy for mood disorders. Int J Neuropsychopharmacol. https ://doi.org/10.1093/ijnp/pyw019

200. Bobinska K, Szemraj J, Czarny P, Galecki P (2016) Expression and activity of metalloproteinases in depression. Med Sci Monit 22:1334-1341

201. Aguayo FI, Pacheco AA, Garcia-Rojo GJ, Pizarro-Bauerle JA, Doberti AV, Tejos M, Garcia-Perez MA, Rojas PS, Fiedler JL (2018) Matrix metalloproteinase 9 displays a particular time response to acute stress: variation in its levels and activity distribution in rat hippocampus. ACS Chem Neurosci 9(5):945-956. https://doi.org/10.1021/acschemneuro.7b00387

202. American Psychiatric Association (2013) Diagnostic and statistical manual of mental disorders: DSM-5, 5th edn. American Psychiatric Association, Washington, DC

203. Abbeduto L, McDuffie A, Thurman AJ (2014) The fragile X syndrome-autism comorbidity: what do we really know? Front Genet 5:355. https://doi.org/10.3389/fgene.2014.00355

204. Dziembowska M, Pretto DI, Janusz A, Kaczmarek L, Leigh MJ, Gabriel N, Durbin-Johnson B, Hagerman RJ, Tassone F (2013) High MMP-9 activity levels in fragile $X$ syndrome are lowered by minocycline. Am J Med Genet A 161A(8):1897-1903. https ://doi.org/10.1002/ajmg.a.36023

205. Leigh MJ, Nguyen DV, Mu Y, Winarni TI, Schneider A, Chechi T, Polussa J, Doucet P, Tassone F, Rivera SM, Hessl D, Hagerman RJ (2013) A randomized double-blind, placebo-controlled trial of minocycline in children and adolescents with fragile X syndrome. J Dev Behav Pediatr 34(3):147-155. https://doi. org/10.1097/DBP.0b013e318287cd17

206. Paribello C, Tao L, Folino A, Berry-Kravis E, Tranfaglia M, Ethell IM, Ethell DW (2010) Open-label add-on treatment trial of minocycline in fragile X syndrome. BMC Neurol 10:91. https ://doi.org/10.1186/1471-2377-10-91

207. Schneider A, Leigh MJ, Adams P, Nanakul R, Chechi T, Olichney J, Hagerman R, Hessl D (2013) Electrocortical changes associated with minocycline treatment in fragile $\mathrm{X}$ syndrome. J Psychopharmacol 27(10):956-963. https://doi.org/10.1177/02698 81113494105

208. Gkogkas CG, Khoutorsky A, Cao R, Jafarnejad SM, PragerKhoutorsky M, Giannakas N, Kaminari A, Fragkouli A, Nader K, Price TJ, Konicek BW, Graff JR, Tzinia AK, Lacaille JC, Sonenberg N (2014) Pharmacogenetic inhibition of eIF4E-dependent Mmp9 mRNA translation reverses fragile X syndrome-like phenotypes. Cell Rep 9(5):1742-1755. https://doi.org/10.1016/j. celrep.2014.10.064

209. Abdallah MW, Pearce BD, Larsen N, Greaves-Lord K, NorgaardPedersen B, Hougaard DM, Mortensen EL, Grove J (2012) Amniotic fluid MMP-9 and neurotrophins in autism spectrum disorders: an exploratory study. Autism Res 5(6):428-433. https ://doi.org/10.1002/aur.1254

210. Fiorentino M, Sapone A, Senger S, Camhi SS, Kadzielski SM, Buie TM, Kelly DL, Cascella N, Fasano A (2016) Blood-brain barrier and intestinal epithelial barrier alterations in autism spectrum disorders. Mol Autism 7:49. https://doi.org/10.1186/s1322 9-016-0110-Z

211. Bilousova TV, Dansie L, Ngo M, Aye J, Charles JR, Ethell DW, Ethell IM (2009) Minocycline promotes dendritic spine maturation and improves behavioural performance in the fragile X mouse model. J Med Genet 46(2):94-102. https://doi. org/10.1136/jmg.2008.061796

212. Nagaoka A, Takehara H, Hayashi-Takagi A, Noguchi J, Ishii K, Shirai F, Yagishita S, Akagi T, Ichiki T, Kasai H (2016) Abnormal intrinsic dynamics of dendritic spines in a fragile $\mathrm{X}$ syndrome mouse model in vivo. Sci Rep 6:26651. https://doi. org/10.1038/srep26651

213. Sidhu H, Dansie LE, Hickmott PW, Ethell DW, Ethell IM (2014) Genetic removal of matrix metalloproteinase 9 rescues 
the symptoms of fragile $\mathrm{X}$ syndrome in a mouse model. $\mathrm{J}$ Neurosci 34(30):9867-9879. https://doi.org/10.1523/JNEUR OSCI.1162-14.2014

214. Lovelace JW, Wen TH, Reinhard S, Hsu MS, Sidhu H, Ethell IM, Binder DK, Razak KA (2016) Matrix metalloproteinase-9 deletion rescues auditory evoked potential habituation deficit in a mouse model of Fragile X Syndrome. Neurobiol Dis 89:126135. https://doi.org/10.1016/j.nbd.2016.02.002

215. Rotschafer SE, Trujillo MS, Dansie LE, Ethell IM, Razak KA (2012) Minocycline treatment reverses ultrasonic vocalization production deficit in a mouse model of Fragile X Syndrome. Brain Res 1439:7-14. https://doi.org/10.1016/j.brain res.2011.12.041

216. Gantois I, Khoutorsky A, Popic J, Aguilar-Valles A, Freemantle E, Cao R, Sharma V, Pooters T, Nagpal A, Skalecka A, Truong VT, Wiebe S, Groves IA, Jafarnejad SM, Chapat C, McCullagh EA, Gamache K, Nader K, Lacaille JC, Gkogkas CG, Sonenberg N (2017) Metformin ameliorates core deficits in a mouse model of fragile X syndrome. Nat Med 23(6):674-677. https ://doi.org/10.1038/nm.4335

217. Wen TH, Binder DK, Ethell IM, Razak KA (2018) The perineuronal 'Safety' net? Perineuronal net abnormalities in neurological disorders. Front Mol Neurosci 11:270. https://doi. org/10.3389/fnmol.2018.00270

218. Yoo MH, Kim TY, Yoon YH, Koh JY (2016) Autism phenotypes in ZnT3 null mice: involvement of zinc dyshomeostasis, MMP-9 activation and BDNF upregulation. Sci Rep 6:28548. https://doi.org/10.1038/srep28548

219. Castagnola S, Bardoni B, Maurin T (2017) The search for an effective therapy to treat fragile $\mathrm{X}$ syndrome: dream or reality? Front Synaptic Neurosci 9:15. https://doi.org/10.3389/fnsyn .2017 .00015

220. Saha S, Chant D, Welham J, McGrath J (2005) A systematic review of the prevalence of schizophrenia. PLoS Med 2(5):e141. https://doi.org/10.1371/journal.pmed.0020141

221. Anderson IM, Haddad PM, Scott J (2012) Bipolar disorder. BMJ 345:e8508. https://doi.org/10.1136/bmj.e8508

222. Beentjes TA, Goossens PJ, Poslawsky IE (2012) Caregiver burden in bipolar hypomania and mania: a systematic review. Perspect Psychiatr Care 48(4):187-197. https://doi.org/10.11 11/j.1744-6163.2012.00328.x

223. Malaspina D, Owen MJ, Heckers S, Tandon R, Bustillo J, Schultz S, Barch DM, Gaebel W, Gur RE, Tsuang M, Van Os J, Carpenter W (2013) Schizoaffective disorder in the DSM-5. Schizophr Res 150(1):21-25. https://doi.org/10.1016/j.schre s.2013.04.026

224. Rybakowski JK, Skibinska M, Kapelski P, Kaczmarek L, Hauser J (2009) Functional polymorphism of the matrix metalloproteinase-9 (MMP-9) gene in schizophrenia. Schizophr Res 109(13):90-93. https://doi.org/10.1016/j.schres.2009.02.005

225. Han H, He X, Tang J, Liu W, Liu K, Zhang J, Wang X, Xu Y, Chen X (2011) The C(-1562)T polymorphism of matrix metalloproteinase-9 gene is associated with schizophrenia in China. Psychiatry Res 190(1):163-164. https://doi.org/10.1016/j.psych res.2011.04.026

226. Lepeta K, Purzycka KJ, Pachulska-Wieczorek K, Mitjans M, Begemann M, Vafadari B, Bijata K, Adamiak RW, Ehrenreich H, Dziembowska M, Kaczmarek L (2017) A normal genetic variation modulates synaptic MMP-9 protein levels and the severity of schizophrenia symptoms. EMBO Mol Med 9(8):1100-1116. https://doi.org/10.15252/emmm.201707723

227. McGregor N, Thompson N, O'Connell KS, Emsley R, van der Merwe L, Warnich L (2018) Modification of the association between antipsychotic treatment response and childhood adversity by MMP9 gene variants in a first-episode schizophrenia cohort. Psychiatry Res 262:141-148. https://doi.org/10.1016/j. psychres.2018.01.044

228. Kucukali CI, Aydin M, Ozkok E, Bilge E, Orhan N, Zengin A, Kara I (2009) Do schizophrenia and bipolar disorders share a common disease susceptibility variant at the MMP3 gene? Prog Neuropsychopharmacol Biol Psychiatry 33(3):557-561. https:// doi.org/10.1016/j.pnpbp.2009.02.012

229. Ali FT, Abd El-Azeem EM, Hamed MA, Ali MAM, Abd AlKader NM, Hassan EA (2017) Redox dysregulation, immunoinflammatory alterations and genetic variants of BDNF and MMP-9 in schizophrenia: pathophysiological and phenotypic implications. Schizophr Res 188:98-109. https://doi. org/10.1016/j.schres.2017.01.016

230. Rahimi S, Sayad A, Moslemi E, Ghafouri-Fard S, Taheri M (2017) Blood assessment of the expression levels of matrix metalloproteinase 9 (MMP9) and its natural inhibitor, TIMP1 genes in Iranian schizophrenic patients. Metab Brain Dis 32(5):15371542. https://doi.org/10.1007/s11011-017-0043-z

231. Jeffries CD, Perkins DO, Fournier M, Do KQ, Cuenod M, Khadimallah I, Domenici E, Addington J, Bearden CE, Cadenhead KS, Cannon TD, Cornblatt BA, Mathalon DH, McGlashan TH, Seidman LJ, Tsuang M, Walker EF, Woods SW (2018) Networks of blood proteins in the neuroimmunology of schizophrenia. Transl Psychiatry 8(1):112. https://doi.org/10.1038/s41398-018-0158-y

232. Yamamori H, Hashimoto R, Ishima T, Kishi F, Yasuda Y, Ohi K, Fujimoto M, Umeda-Yano S, Ito A, Hashimoto K, Takeda M (2013) Plasma levels of mature brain-derived neurotrophic factor (BDNF) and matrix metalloproteinase-9 (MMP-9) in treatmentresistant schizophrenia treated with clozapine. Neurosci Lett 556:37-41. https://doi.org/10.1016/j.neulet.2013.09.059

233. Chang SH, Chiang SY, Chiu CC, Tsai CC, Tsai HH, Huang CY, Hsu TC, Tzang BS (2011) Expression of anti-cardiolipin antibodies and inflammatory associated factors in patients with schizophrenia. Psychiatry Res 187(3):341-346. https://doi. org/10.1016/j.psychres.2010.04.049

234. Devanarayanan S, Nandeesha H, Kattimani S, Sarkar S (2016) Relationship between matrix metalloproteinase- 9 and oxidative stress in drug-free male schizophrenia: a case control study. Clin Chem Lab Med 54(3):447-452. https://doi.org/10.1515/ cclm-2015-0212

235. Kumarasinghe N, Beveridge NJ, Gardiner E, Scott RJ, Yasawardene S, Perera A, Mendis J, Suriyakumara K, Schall U, Tooney PA (2013) Gene expression profiling in treatment-naive schizophrenia patients identifies abnormalities in biological pathways involving AKT1 that are corrected by antipsychotic medication. Int J Neuropsychopharmacol 16(7):1483-1503. https://doi. org/10.1017/S1461145713000035

236. Rybakowski JK, Skibinska M, Leszczynska-Rodziewicz A, Kaczmarek L, Hauser J (2009) Matrix metalloproteinase-9 gene and bipolar mood disorder. Neuromol Med 11(2):128-132. https:// doi.org/10.1007/s12017-009-8072-3

237. Rybakowski JK, Remlinger-Molenda A, Czech-Kucharska A, Wojcicka M, Michalak M, Losy J (2013) Increased serum matrix metalloproteinase-9 (MMP-9) levels in young patients during bipolar depression. J Affect Disord 146(2):286-289. https://doi. org/10.1016/j.jad.2012.07.019

238. Sodersten K, Palsson E, Ishima T, Funa K, Landen M, Hashimoto K, Agren H (2014) Abnormality in serum levels of mature brainderived neurotrophic factor (BDNF) and its precursor proBDNF in mood-stabilized patients with bipolar disorder: a study of two independent cohorts. J Affect Disord 160:1-9. https://doi. org/10.1016/j.jad.2014.01.009

239. Drago A, Monti B, De Ronchi D, Serretti A (2014) Genetic variations within metalloproteinases impact on the prophylaxis of depressive phases in bipolar patients. Neuropsychobiology 69(2):76-82. https://doi.org/10.1159/000356971 
240. Frye MA, Nassan M, Jenkins GD, Kung S, Veldic M, Palmer BA, Feeder SE, Tye SJ, Choi DS, Biernacka JM (2015) Feasibility of investigating differential proteomic expression in depression: implications for biomarker development in mood disorders. Transl Psychiatry 5:e689. https://doi.org/10.1038/tp.2015.185

241. Nassan M, Jia YF, Jenkins G, Colby C, Feeder S, Choi DS, Veldic M, McElroy SL, Bond DJ, Weinshilboum R, Biernacka JM, Frye MA (2017) Exploring hepsin functional genetic variation association with disease specific protein expression in bipolar disorder: applications of a proteomic informed genomic approach. J Psychiatr Res 95:208-212. https://doi.org/10.1016/j. jpsychires.2017.07.005

242. American Psychiatric Association (2000) Diagnostic and statistical manual of mental disorders: DSM-IV-TR, 4th edn. American Psychiatric Association, Washington, DC

243. Grant JE, Potenza MN, Weinstein A, Gorelick DA (2010) Introduction to behavioral addictions. Am J Drug Alcohol Abuse 36(5):233-241. https://doi.org/10.3109/00952990.2010.491884

244. Volkow ND, Morales M (2015) The brain on drugs: from reward to addiction. Cell 162(4):712-725. https://doi.org/10.1016/j. cell.2015.07.046

245. Torregrossa MM, Corlett PR, Taylor JR (2011) Aberrant learning and memory in addiction. Neurobiol Learn Mem 96(4):609-623. https://doi.org/10.1016/j.nlm.2011.02.014

246. Smith AC, Scofield MD, Kalivas PW (2015) The tetrapartite synapse: extracellular matrix remodeling contributes to corticoaccumbens plasticity underlying drug addiction. Brain Res 1628(Pt A):29-39. https://doi.org/10.1016/j.brainres.2015.03.027

247. Mash DC, ffrench-Mullen J, Adi N, Qin Y, Buck A, Pablo J (2007) Gene expression in human hippocampus from cocaine abusers identifies genes which regulate extracellular matrix remodeling. PLoS One 2(11):e1187. https://doi.org/10.1371/ journal.pone. 0001187

248. Kovatsi L, Batzios S, Nikolaou K, Fragou D, Njau S, Tsatsakis A, Karakiulakis G, Papakonstantinou E (2013) Alterations in serum MMP and TIMP concentrations following chronic heroin abuse. Toxicol Mech Methods 23(5):377-381. https://doi. org/10.3109/15376516.2012.758681

249. Sillanaukee P, Kalela A, Seppa K, Hoyhtya M, Nikkari ST (2002) Matrix metalloproteinase- 9 is elevated in serum of alcohol abusers. Eur J Clin Investig 32(4):225-229

250. Wang Q, Ishikawa T, Michiue T, Zhu BL, Guan DW, Maeda H (2014) Molecular pathology of brain matrix metalloproteases, claudin5, and aquaporins in forensic autopsy cases with special regard to methamphetamine intoxication. Int J Legal Med 128(3):469-474. https://doi.org/10.1007/s00414-014-0972-6

251. Samochowiec A, Grzywacz A, Kaczmarek L, Bienkowski P, Samochowiec J, Mierzejewski P, Preuss UW, Grochans E, Ciechanowicz A (2010) Functional polymorphism of matrix metalloproteinase-9 (MMP-9) gene in alcohol dependence: family and case control study. Brain Res 1327:103-106. https://doi. org/10.1016/j.brainres.2010.02.072

252. Nakamoto K, Kawasaki S, Kobori T, Fujita-Hamabe W, Mizoguchi H, Yamada K, Nabeshima T, Tokuyama S (2012) Involvement of matrix metalloproteinase- 9 in the development of morphine tolerance. Eur J Pharmacol 683(1-3):86-92. https://doi. org/10.1016/j.ejphar.2012.03.006

253. Liu Y, Brown S, Shaikh J, Fishback JA, Matsumoto RR (2008) Relationship between methamphetamine exposure and matrix metalloproteinase 9 expression. NeuroReport 19(14):1407-1409. https://doi.org/10.1097/WNR.0b013e32830dd606

254. Mizoguchi H, Yamada K, Niwa M, Mouri A, Mizuno T, Noda Y, Nitta A, Itohara S, Banno Y, Nabeshima T (2007) Reduction of methamphetamine-induced sensitization and reward in matrix metalloproteinase-2 and -9-deficient mice.
J Neurochem 100(6):1579-1588. https://doi.org/10.111 $1 / \mathrm{j} .1471-4159.2006 .04288 . x$

255. Natarajan R, Harding JW, Wright JW (2013) A role for matrix metalloproteinases in nicotine-induced conditioned place preference and relapse in adolescent female rats. J Exp Neurosci 7:1-14. https://doi.org/10.4137/JEN.S11381

256. Smith AW, Nealey KA, Wright JW, Walker BM (2011) Plasticity associated with escalated operant ethanol self-administration during acute withdrawal in ethanol-dependent rats requires intact matrix metalloproteinase systems. Neurobiol Learn Mem 96(2):199-206. https://doi.org/10.1016/j.nlm.2011.04.011

257. Stefaniuk M, Beroun A, Lebitko T, Markina O, Leski S, Meyza K, Grzywacz A, Samochowiec J, Samochowiec A, Radwanska K, Kaczmarek L (2017) Matrix metalloproteinase-9 and synaptic plasticity in the central amygdala in control of alcoholseeking behavior. Biol Psychiatry 81(11):907-917. https://doi. org/10.1016/j.biopsych.2016.12.026

258. Wright JW, Masino AJ, Reichert JR, Turner GD, Meighan SE, Meighan PC, Harding JW (2003) Ethanol-induced impairment of spatial memory and brain matrix metalloproteinases. Brain Res 963(1-2):252-261

259. Brown TE, Forquer MR, Cocking DL, Jansen HT, Harding JW, Sorg BA (2007) Role of matrix metalloproteinases in the acquisition and reconsolidation of cocaine-induced conditioned place preference. Learn Mem 14(3):214-223. https://doi.org/10.1101/ $\operatorname{lm} .476207$

260. Brown TE, Forquer MR, Harding JW, Wright JW, Sorg BA (2008) Increase in matrix metalloproteinase-9 levels in the rat medial prefrontal cortex after cocaine reinstatement of conditioned place preference. Synapse 62(12):886-889. https://doi. org/10.1002/syn.20562

261. Mizoguchi H, Yamada K, Mouri A, Niwa M, Mizuno T, Noda Y, Nitta A, Itohara S, Banno Y, Nabeshima T (2007) Role of matrix metalloproteinase and tissue inhibitor of MMP in methamphetamine-induced behavioral sensitization and reward: implications for dopamine receptor down-regulation and dopamine release. J Neurochem 102(5):1548-1560. https://doi.org/10.11 11/j.1471-4159.2007.04623.x

262. Mizoguchi H, Yamada K, Nabeshima T (2008) Neuropsychotoxicity of abused drugs: involvement of matrix metalloproteinase- 2 and -9 and tissue inhibitor of matrix metalloproteinase- 2 in methamphetamine-induced behavioral sensitization and reward in rodents. J Pharmacol Sci 106(1):9-14

263. Van den Oever MC, Lubbers BR, Goriounova NA, Li KW, Van der Schors RC, Loos M, Riga D, Wiskerke J, Binnekade R, Stegeman M, Schoffelmeer AN, Mansvelder HD, Smit AB, De Vries TJ, Spijker S (2010) Extracellular matrix plasticity and GABAergic inhibition of prefrontal cortex pyramidal cells facilitates relapse to heroin seeking. Neuropsychopharmacology 35(10):2120-2133. https://doi.org/10.1038/npp.2010.90

264. Kalivas PW, Volkow ND (2011) New medications for drug addiction hiding in glutamatergic neuroplasticity. Mol Psychiatry 16(10):974-986. https://doi.org/10.1038/mp.2011.46

265. Liao D, Hessler NA, Malinow R (1995) Activation of postsynaptically silent synapses during pairing-induced LTP in CA1 region of hippocampal slice. Nature 375(6530):400-404. https ://doi.org/10.1038/375400a0

266. Huang $\mathrm{YH}$, Lin $\mathrm{Y}, \mathrm{Mu} \mathrm{P}$, Lee BR, Brown TE, Wayman G, Marie H, Liu W, Yan Z, Sorg BA, Schluter OM, Zukin RS, Dong Y (2009) In vivo cocaine experience generates silent synapses. Neuron 63(1):40-47. https://doi.org/10.1016/j.neuro n.2009.06.007

267. Graziane NM, Sun S, Wright WJ, Jang D, Liu Z, Huang YH, Nestler EJ, Wang YT, Schlüter OM, Dong Y (2016) Opposing mechanisms mediate morphine- and cocaine-induced generation 
of silent synapses. Nat Neurosci 19(7):915-925. https://doi. org/10.1038/nn.4313

Publisher's Note Springer Nature remains neutral with regard to jurisdictional claims in published maps and institutional affiliations. 